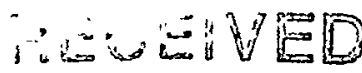 \\ OCT 162890 \\ OSTI
}

LBNL-41846

\section{India's Fertilizer Industry: Productivity and Energy Efficiency}

\author{
Katja Schumacher and Jayant Sathaye
}

\author{
Energy Analysis Program \\ Environmental Energy Technologies Division \\ Ernest Orlando Lawrence Berkeley National Laboratory \\ University of California \\ Berkeley, California 94720
}

July 1999

This work was supported by the Director, Office of Science, Office of Biological and Environmental Research, Environmental Sciences Division, of the U.S. Department of Energy under Contract No. DE-AC03-76SF00098. 


\section{ACKNOWLEDGEMENTS}

The authors would like to thank Joyashree Roy, Ernst Worrell, Puran Mongia, and Alan Sanstad for their valuable assistance and comments on previous drafts of this paper. This work was supported by the Environmental Science Division, Office of Biological and Environmental Research (OBER), Office of Energy Research, U.S. Department of Energy, under Contract No. DE-AC03-76SF00098. 


\section{DISCLAIMER}

This report was prepared as an account of work sponsored by an agency of the United States Government. Neither the United States Government nor any agency thereof, nor any of their employees, make any warranty, express or implied, or assumes any legal liability or responsibility for the accuracy, completeness, or usefulness of any information, apparatus, product, or process disclosed, or represents that its use would not infringe privately owned rights. Reference herein to any specific commercial product, process, or service by trade name, trademark, manufacturer, or otherwise does not necessarily constitute or imply its endorsement, recommendation, or favoring by the United States Government or any agjericy thereof. The views and opinions of authors expressed herein do not necessarily state or reflect those of the United States Government or any agency thereof. 


\section{DISCLAIMER}

Portions of this document may be illegible in electronic image products. Images are produced from the best available original document. 


\begin{abstract}
Historical estimates of productivity growth in India's fertilizer sector vary from indicating an improvement to a decline in the sector's productivity. The variance may be traced to the time period of study, source of data for analysis, and type of indices and econometric specifications used for reporting productivity growth. We derive both growth accounting and econometric estimates of productivity growth for this sector. Our results show that over the observed period from 1973-74 to 1993-94 productivity increased by $2.3 \%$ p.a. as indicated by the Translog index. Calculations of the Kendrick and Solow index support this finding. The increase took place during the era of total control when a retention price system and distribution control was in effect. The retention price system was coupled with relatively high norms on capacity utilization which supported productivity increase. With liberalization of the fertilizer sector and reduction of subsidies productivity declined substantially since the early $1990 \mathrm{~s}$, despite an increase in capacity utilization. Using a translog specification the econometric analysis reveals that technical progress in India's fertilizer sector has been biased towards the use of energy, while it has been capital and labor saving. The analysis of current changes in structure and energy efficiency in the sector demonstrates the major role policies and fiscal incentives play in the Indian fertilizer sector. Substantial energy savings and carbon reduction potential exists. Energy policies can help overcome barriers to the adoption of energy efficiency measures in giving proper incentives and correcting distorted prices.
\end{abstract}




\section{Table of Contents}

List of Tables $\quad$ vi

List of Figures vii

1. Introduction 1

2. Fertilizer Industry 2

2.1. The Fertilizer Industry in Context 2

2.2. Fertilizer Process 3

2.3. Fertilizer Production in India 5

2.3.1. Raw Materials $\quad 8$

2.3.2. Energy Use 9

2.4. Past and Future Demand 10

$\begin{array}{lr}\text { 2.5. Policy } & 11\end{array}$

3. Statistical and Econometric Analysis 16

3.1. Statistical Analysis $\quad 16$

$\begin{array}{lr}\text { 3.1.1. Previous Studies } & 17\end{array}$

$\begin{array}{ll}\text { 3.1.1.1. } & \text { Partial Productivity }\end{array}$

3.1.1.2. Total Factor Productivity Growth 21

3.1.2. Own Estimates $\quad 21$

$\begin{array}{ll}\text { 3.1.2.1. Partial Productivity } & 21\end{array}$

3.1.2.2. Total Factor Productivity 23

3.1.2.3. Total Productivity 24

3.2. Econometric Analysis $\quad 26$

3.2.1. Previous Studies $\quad 26$

$\begin{array}{ll}\text { 3.2.2. Own Estimates } & 27\end{array}$

$\begin{array}{lr}\text { 3.3. Discussion } & 28\end{array}$ 
4. Future Development of the Fertilizer Sector

4.1. Ongoing Changes in the Fertilizer Industry

4.2. Potentials for Energy Efficiency Improvements

4.2.1. India versus Best Practice

4.2.2. Categories for Energy Efficiency Improvement

33

4.2.3. Barriers to Energy Efficiency Improvement

5. Summary and Conclusions

References

Appendix

38 


\section{List of Tables}

Table 2.1 Economic Indicators for the Fertilizer Industry

Table 2.2 Production of Fertilizer by Products

Table 2.3 Fertilizer Production, Capacity and Capacity Utilization

Table 2.4 Fertilizer Production, Capacity and Capacity Utilization by Sector (1991)

Table 2.5 Share of Fertilizer Products in Total Nutrient Production (1990-91)

Table 2.6 Specific Final Energy Consumption of Ammonia Plants: Average and by Feedstock

Table 2.7 Fertilizer Consumption, Imports and Subsidies

Table 2.8 Demand Projections - Fertilizer

Table 2.9 Overview of Policies Regarding the Fertilizer Industry

Table 3.1 Partial Productivity Growth

Table 3.2 Total Factor Productivity Growth

Table 3.3 Total Productivity Growth

Table 3.4 Decomposition of Growth in Value of Output

Table 3.5 Estimated Parameters for the Translog Cost Function Approach

Table 3.6 Technical Change Bias

Table 3.7 Price Elasticities

Table 3.8 Elasticities of Substitution - Qualitative Overview

Table 4.1 Age, Number, Installed Capacity and Feedstock of Ammonia Plants in India Table 4.2 Energy Savings Potential - All Ammonia Plants: Broad Estimates 


\section{List of Figures}

Figure 2.1 Changes in Physical Energy Intensity of Various Industries

Figure 3.1 Estimates of Total Factor Productivity Growth

Figure 3.2 Estimates of Partial Productivity Growth: Capital

Figure 3.3 Estimates of Partial Productivity Growth: Labor

Figure 3.4 Estimates of Capital-Labor Ratio

Figure 3.5 Index of Partial Productivity

Figure 3.6 Index of Total Factor Productivity

Figure 3.7 Index of Total Productivity 


\section{Introduction}

The fertilizer industry presents one of the most energy intensive sectors within the Indian economy and is therefore of particular interest in the context of both local and global environmental discussions. Increases in productivity through the adoption of more efficient and cleaner technologies in the manufacturing sector will be most effective in merging economic, environmental, and social development objectives. A historical examination of productivity growth in India's industries embedded into a broader analysis of structural composition and policy changes will help identify potential future development strategies that lead towards a more sustainable development path.

Issues of productivity growth and patterns of substitution in the fertilizer sector as well as in other energy intensive industries in India have been discussed from various perspectives. Historical estimates vary from indicating an improvement to a decline in the sector's productivity. The variation depends mainly on the time period considered, the source of data, the type of indices and econometric specifications used for reporting productivity growth. Regarding patterns of substitution most analyses focus on interfuel substitution possibilities in the context of rising energy demand. Not much research has been conducted on patterns of substitution among the primary and secondary input factors: Capital, labor, energy and materials. However, analyzing the use and substitution possibilities of these factors as well as identifying the main drivers of productivity growth among these and other factors is of special importance for understanding technological and overall development of an industry.

In this paper we contribute to the discussion on productivity growth and the role of technological change. We introduce the fertilizer industry in more detail taking into account industry specific aspects such as structural composition, production, technologies, energy consumption within processes, sector specific policies etc. This following we derive both statistical and econometric estimates of productivity growth for the fertilizer sector over time. For the statistical analysis we develop the Kendrick and Solow indices while for the econometric analysis a translog cost function approach using both cross-state and national time series data is employed. The results are then interpreted within a broader context of structural and policy changes in the sector as well as other sector specific aspects.

Future energy use depends on the level of production and the technologies employed. Furthermore, different economic and policy settings affect structures and efficiencies within the sector. The final section therefore examines the ongoing changes in the fertilizer industry structure. It compares best practice technologies to Indian technologies and identify potentials and barriers to the adoption of such efficiency improvements. 


\section{Fertilizer Industry}

\subsection{The Fertilizer Industry in Context}

Six industries in India have been identified as energy intensive industries: Aluminum, cement, fertilizer, iron and steel, glass, and paper. Together they account for $16.8 \%$ of manufacturing value of output (VO) and consume $38.8 \%$ of all fuels consumed in the manufacturing sector (Table 2.1). The fertilizer sector holds a considerable share within these energy intensive industries. In 1993, it accounted for $23 \%$ of value of output within the six industries and for $3.8 \%$ in the manufacturing sector.

Table 2.1: Economic Indicators for the Fertilizer Industry

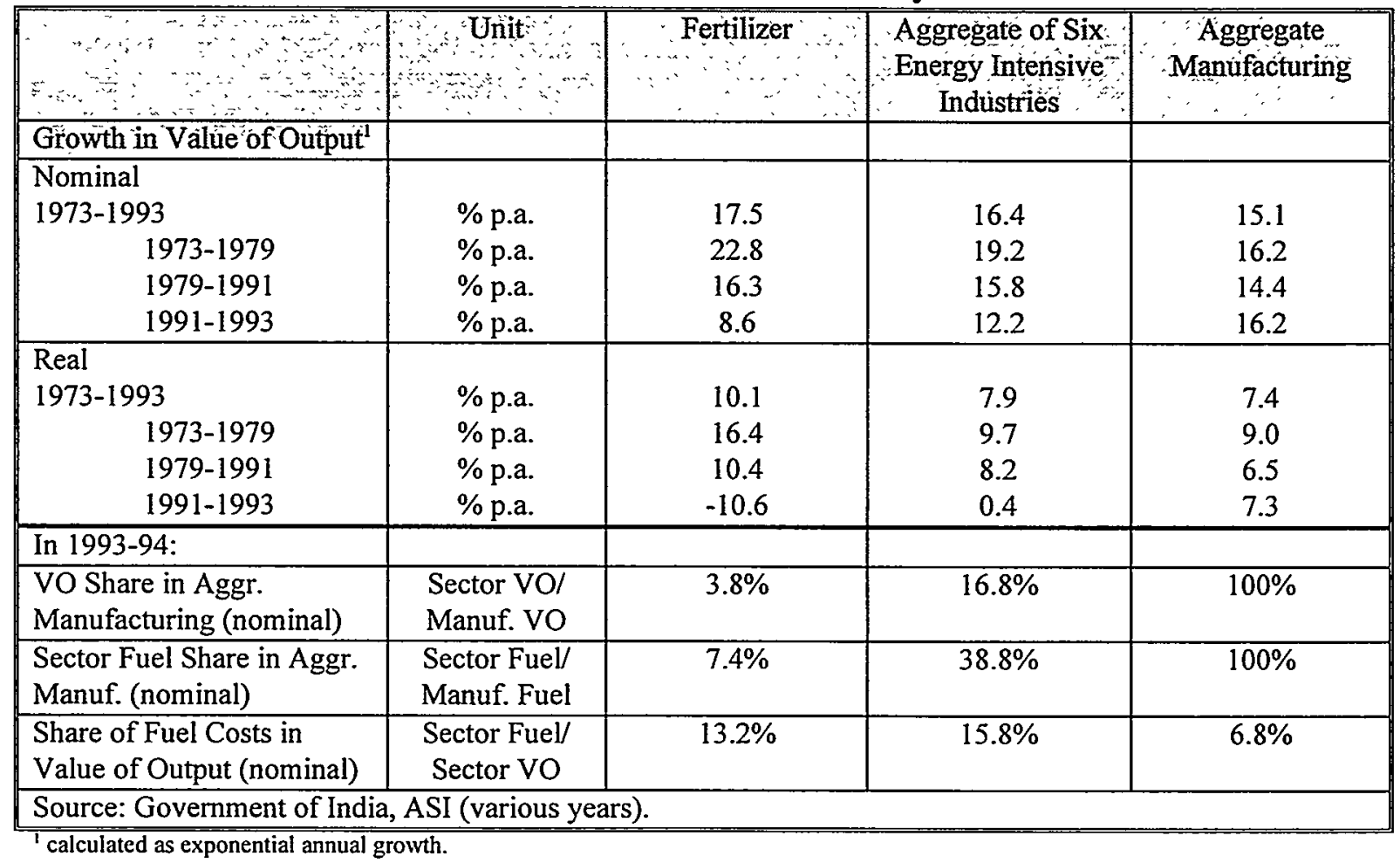

Production in the fertilizer sector has been increasing over the last 20 years. Over the study period 1973-1993 real VO increased by an average of 10.1\% p.a. The fertilizer industry shows highest growth in the group of energy intensive industries. Major fertilizer pricing specific policy changes took place in 1977-80 and since 1991. As seen in Table 2.1 growth of real value of output was rising at around $16.4 \%$ during the first period (1973-1979) and increased slightly lower at $10.4 \%$ in the following period of total control (1979-91) accounting for higher than average growth in both the group of six energy intensive industries and total manufacturing. After 1991, real value of output decreased substantially at $-10.6 \%$ until 1993 despite major policy changes towards decontrol and liberalization that aimed at spurring the sector. 
Figure 2.1: Changes in Physical Energy Intensity of Various Industries (Real Fuel Cost/Real Value of Output - 1973-74 values)

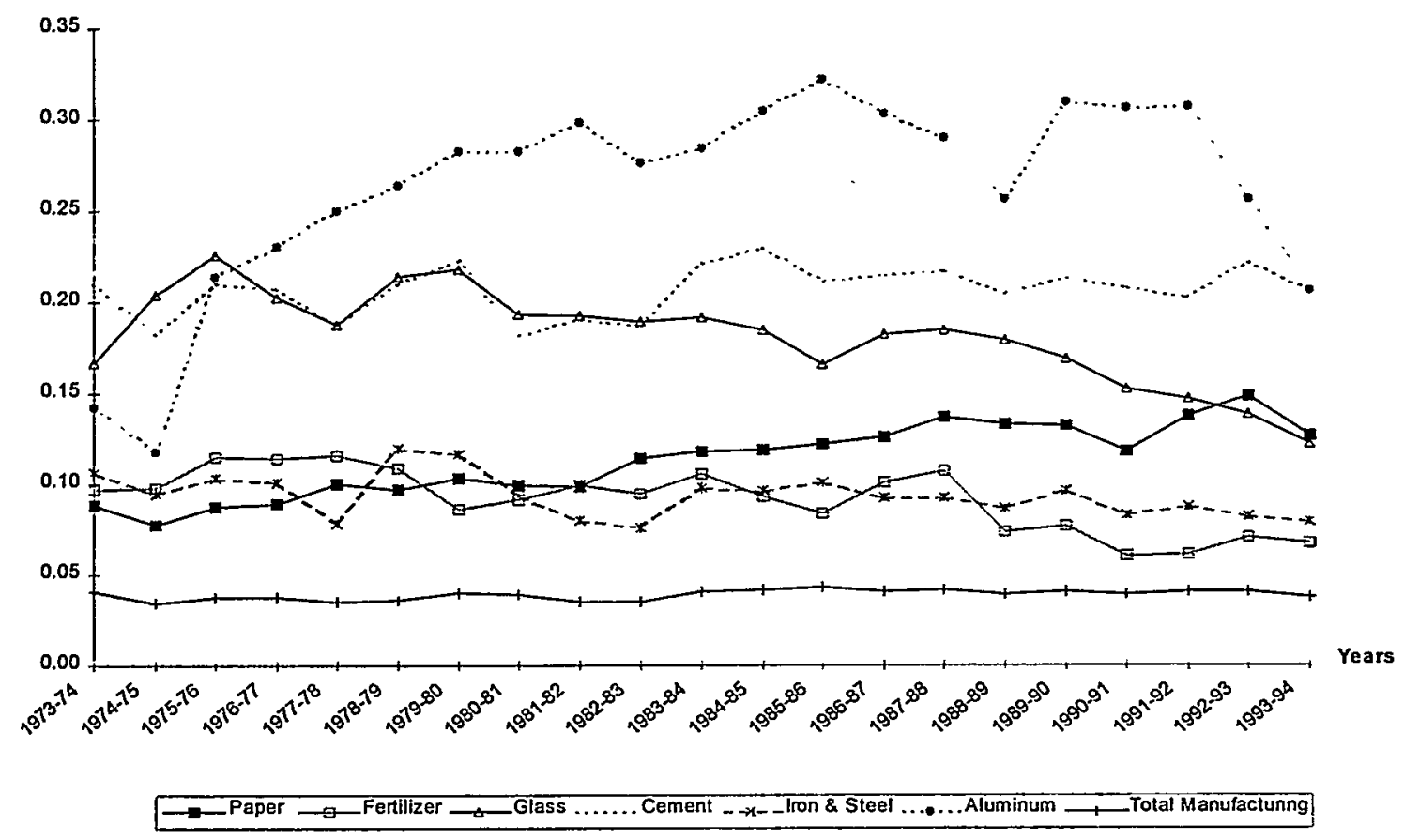

In 1993-94, the fertilizer sector accounts for $7.4 \%$ of total fuels consumed in the manufacturing sector. Within the group of energy intensive industries, the share of fuels consumed per unit of output (VO) is second lowest (13.2\%) after the iron and steel industry and thus less than the average of the six energy intensive industries. However, fuels consumed per unit of output are still about twice the average of total manufacturing unit fuel costs. Figure 2.1 displays the energy intensity of the fertilizer sector in real values. The 'real-value' indicator reflects the changes in physical energy intensity over time and gives a comparison to other sectors. Besides iron and steel production, fertilizer production has been least energy intensive not only in 1993 but almost over the whole time period. Overall, despite its fluctuating pattern the fertilizer industry shows a relatively stable slightly decreasing trend in energy intensity.

\subsection{Fertilizer Process}

Agricultural growth is mainly dependent on advances in farming technologies and increased use of chemical fertilizers. The fertilizers contain the three basic nutrients for agriculture: nitrogen $(N)$, phosphorous $(P)$ and potassium $(K)$. Nitrogen is primarily provided by nitrogenous fertilizers such as urea $(46 \% \mathrm{~N})$ or ammonia fertilizers, e.g. ammonium sulfate $(20.6 \% \mathrm{~N})$. Further shares of nitrogen are contained in complex fertilizers that combine all three plant nutrients (NPK). Phosphate comes in the form of straight phosphatic fertilizers such as single super phosphate $\left(16 \% \mathrm{P}_{2} \mathrm{O}_{5}\right)$ or as part of a complex fertilizer. Potassic fertilizer is available as straight potassic fertilizer, such as 
muriate of potash $\left(60 \% \mathrm{~K}_{2} \mathrm{O}\right)$ or sulfate of potash $\left(50 \% \mathrm{~K}_{2} \mathrm{O}\right)$ or as a complex NPK fertilizer component.

The effectiveness of fertilizers can only be assured if applied in optimal combination specific to the local soil and climatic conditions. Nitrogen presents the most essential nutrient for plant growth holding the biggest share in the optimal mix. The basic raw material for the production of nitrogenous fertilizers is ammonia, for straight phosphatic fertilizers it is phosphate and for potassic fertilizers potash. Out of the three fertilizer types, production of ammonia is most energy and resources intensive. Its production process is presented in more detail here. The description draws on Phylipsen, Blok and Worrell (1998).

The most important step in producing ammonia $\left(\mathrm{NH}_{3}\right)$ is the production of hydrogen, which is followed by the reaction between hydrogen and nitrogen. A number of processes are available to produce hydrogen, differing primarily in type of feedstock used.

The hydrogen production route predominantly used world wide is steam reforming of natural gas. In this process natural gas $\left(\mathrm{CH}_{4}\right)$ is mixed with water (steam) and air to produce hydrogen $\left(\mathrm{H}_{2}\right)$, carbon monoxide $(\mathrm{CO})$ and carbon dioxide $\left(\mathrm{CO}_{2}\right)$. Waste heat is used for preheating and steam production, and part of the methane is burnt to generate the energy required to drive the reaction. $\mathrm{CO}$ is further converted to $\mathrm{CO}_{2}$ and $\mathrm{H}_{2}$ using the water gas shift reaction. After $\mathrm{CO}$ and $\mathrm{CO}_{2}$ is removed from the gas mixture ammonia $\left(\mathrm{NH}_{3}\right)$ is obtained by synthesis reaction.

Another route to produce ammonia is through partial oxidation. This process requires more energy (up to $40-50 \%$ more) and is more expensive than steam reforming. The advantage of partial oxidation is a high feedstock flexibility: it can be used for any gaseous, liquid or solid hydrocarbon. In practice partial oxidation can be economically viable if used for conversion of relatively cheap raw materials like oil residues or coal. In this process air is distilled to produce oxygen for the oxidation step. A mixture containing among others $\mathrm{H}_{2}, \mathrm{CO}, \mathrm{CO}_{2}$ and $\mathrm{CH}_{4}$ is formed. After desulfurization $\mathrm{CO}$ is converted to $\mathrm{CO}_{2}$ and $\mathrm{H}_{2} \mathrm{O} . \mathrm{CO}_{2}$ is removed, and the gas mixture is washed with liquid nitrogen (obtained from the distillation of air). The nitrogen removes $\mathrm{CO}$ from the gas mixture and simultaneously provides the nitrogen required for the ammonia synthesis reaction.

A variety of nitrogenous fertilizers can be produced on the base of ammonia. Ammonia can be used in a reaction with carbon dioxide to produce urea. Ammonia nitrate can be produced through the combination of ammonia and nitric acid adding further energy in form of steam and electricity. Other fertilizer types produced on the base of ammonia include calcium ammonium nitrate (ammonium nitrate mixed with ground dolomite) and NP/NPK compound fertilizers. For the most part further energy is required to induce the necessary chemical processes. 
Phosphatic fertilizers are produced on the basis of phosphoric and sulfuric acids. Phosphoric acid is produced by leaching of phosphate rock with sulfuric acid. Sulfuric acid very often remains as a waste product of the chemical industry. (Worrell et al., 1994)

Potash fertilizers are produced from sylvinite salt. Sylvinite is diluted in a circulation fluid in the flotation process. The potash fertilizer is separated by skimming the solution. (Worrell et al., 1994)

\subsection{Fertilizer Production in India}

India is the fourth largest producer as well as consumer of fertilizer in the world. With population growing at a fast rate, food production was given highest priority in India since the 1960s (New Agricultural Strategy). Although India's soil is varied and rich, it is naturally deficient in major plant nutrients (nitrogen, phosphate and potassium). Growth in chemical fertilizer production and consumption therefore presents the single largest contributor to agricultural progress, its technological transformation and commercialization.

Table 2.2: Production of Fertilizer by Products

\begin{tabular}{|c|c|c|c|c|c|c|c|c|}
\hline Year & $\begin{array}{c}1987- \\
88\end{array}$ & $\begin{array}{c}1988- \\
89\end{array}$ & 1989- & $\begin{array}{l}1990- \\
\therefore 91 \div\end{array}$ & $\begin{array}{l}1991- \\
92\end{array}$ & $\begin{array}{l}1992- \\
93\end{array}$ & $\begin{array}{l}1993- \\
=94 .\end{array}$ & $\begin{array}{r}1994- \\
\hdashline 95\end{array}$ \\
\hline Nitrogenous Fertilizers & 5,467 & 6,712 & 6,747 & 6,993 & 7,302 & 7,431 & 7,231 & 7,944 \\
\hline $\begin{array}{l}\text { Straight Nitrogenous } \\
\text { Fertilizer: }\end{array}$ & 4,764 & 5,729 & 5,991 & 6,148 & 6,156 & 6,321 & 6,376 & 6,801 \\
\hline $\begin{array}{l}\text { Ammonium Sulfate } \\
(20.6 \% \mathrm{~N})\end{array}$ & 539 & 610 & 586 & 558 & 553 & 563 & 620 & 585 \\
\hline Urea $(46 \% N)$ & 9,835 & 11,867 & 12,486 & 12,836 & 12,832 & 13,126 & 13,150 & 14,137 \\
\hline $\begin{array}{l}\text { Calcium Ammonium } \\
\text { Nitrate }(25 \% N)\end{array}$ & 421 & 480 & 425 & 436 & 446 & 546 & 666 & 572 \\
\hline $\begin{array}{l}\text { Ammonium Chloride } \\
(25 \% N)\end{array}$ & 87 & 97 & 80 & 79 & 112 & 122 & 131 & 137 \\
\hline $\begin{array}{l}\text { Nitrogenous Fertilizer } \\
\text { through NP/NPK }\end{array}$ & 703 & 984 & 757 & 845 & 1,145 & 1,110 & 855 & 1,144 \\
\hline Phosphatic Fertilizers & 1,666 & 2,253 & 1,795 & 2,051 & 2,562 & 2,321 & 1,874 & 2,557 \\
\hline $\begin{array}{l}\text { Straight Phosphatic } \\
\text { Fertilizer: }\end{array}$ & 398 & 471 & 502 & 584 & 478 & 373 & 361 & 484 \\
\hline $\begin{array}{l}\text { Single Super } \\
\text { Phosphate }\left(16 \% \mathrm{P}_{2} \mathrm{O}_{5}\right)\end{array}$ & 397 & 471 & 502 & 584 & 478 & 373 & 361 & 484 \\
\hline $\begin{array}{l}\text { Phosphatic Fertilizer } \\
\text { through NP/NPK }\end{array}$ & 1,268 & 1,781 & 1,293 & 1,467 & 2,084 & 1,948 & 1,513 & 2,073 \\
\hline
\end{tabular}

Fertilizer production in India has been growing at an accelerating rate, from very low levels after independence ( 0.04 million tonnes $^{1}$ in 1951) and still low levels in the early 1970s to a total production of 11.36 million tonnes in 1995 (Table 2.3). Currently, India produces various kinds of both nitrogenous and phosphatic fertilizers domestically (see

' metric tonnes, sometimes abbreviated as $\mathrm{t}$, or million tonnes as $\mathrm{Mt}$ in the following. 
Table 2.2). These include straight nitrogenous fertilizers (urea and ammonium), straight phosphatic fertilizers (single super phosphate) and complex fertilizers (like di-ammonium phosphate (DAP)). Potassic fertilizers are not manufactured domestically due to lack of indigenous reserves of potash, the main input. The capacity of nitrogenous fertilizer has almost doubled with the commissioning of large sized gas based fertilizer plants in the 1980s. Capacity utilization has increased considerably from around $60 \%$ in $1979-80$ to over $90 \%$ in the 1990 s.

External factors such as weather and monsoon conditions as well as policy changes regarding fertilizer production, use and agricultural output enhancement exert significant influence on capacity utilization in the industry. For instance, following the decontrol of price and distribution of potassic and phosphatic fertilizers in 1992 capacity utilization for phosphatic plants fell to $66.3 \%$ in 1993-94 from a high at $92.4 \%$ in $1991-92$. However, immediately thereafter capacity utilization improved remarkably again to $90.5 \%$ in $1994-95$.

Table 2.3: Fertilizer Production, Capacity and Capacity Utilization (million tonnes of nutrients)

\begin{tabular}{|c|c|c|c|c|c|c|c|c|c|}
\hline \multirow[t]{2}{*}{ Year } & \multicolumn{3}{|c|}{ Production } & \multicolumn{3}{|c|}{ Capacity } & \multicolumn{3}{|c|}{ Capacity Utilization } \\
\hline & $\mathrm{N}$ & $\mathrm{P}_{2} \mathrm{O}_{5}$ & Total & $\mathrm{N}$ & $\mathrm{P}_{2} \mathrm{O}_{5}$ & Total & $\mathrm{N}$ & $\mathrm{P}_{2} \mathrm{O}_{5}$ & Total \\
\hline $1973-74$ & 1.05 & 0.32 & 1.37 & & & & & & \\
\hline 1979-80 & 2.22 & 0.76 & 2.98 & 3.90 & 1.28 & 5.18 & $56.9 \%$ & $59.4 \%$ & $57.5 \%$ \\
\hline $1985-86$ & 4.32 & 1.43 & 5.75 & $5.9 \overline{2}$ & 1.72 & 7.64 & $73.0 \%$ & $83.1 \%$ & $75.3 \%$ \\
\hline 1986-87 & 5.41 & 1.44 & 6.85 & 6.76 & 2.32 & 9.08 & $80.0 \%$ & $62.1 \%$ & $75.4 \%$ \\
\hline $1987-88$ & 5.47 & 1.67 & 7.14 & 7.08 & 2.47 & 9.55 & $77.3 \%$ & $67.6 \%$ & $74.8 \%$ \\
\hline $1988-89$ & 6.71 & 2.25 & 8.96 & 8.16 & 2.67 & 10.83 & $82.2 \%$ & $84.3 \%$ & $82.7 \%$ \\
\hline $1989-90$ & 6.74 & 1.79 & 8.53 & 8.15 & 2.72 & 10.87 & $82.7 \%$ & $65.8 \%$ & $78.5 \%$ \\
\hline $1990-91$ & 6.99 & 2.05 & 9.04 & 8.15 & 2.75 & 10.90 & $85.8 \%$ & $74.5 \%$ & $82.9 \%$ \\
\hline 1991-92 & 7.30 & 2.56 & 9.86 & 8.21 & 2.77 & 10.98 & $88.9 \%$ & $92.4 \%$ & $89.8 \%$ \\
\hline 1992-93 & 7.43 & 2.32 & 9.75 & 8.51 & 2.81 & 11.32 & $87.3 \%$ & $82.6 \%$ & $86.1 \%$ \\
\hline 1993-94 & 7.23 & 1.87 & 9.10 & 8.51 & 2.82 & 11.33 & $85.0 \%$ & $66.3 \%$ & $80.3 \%$ \\
\hline 1994-95 & 7.94 & 2.56 & 10.50 & 8.84 & 2.83 & 11.67 & $89.8 \%$ & $90.5 \%$ & $90.0 \%$ \\
\hline 1995-96 & 8.77 & 2.59 & 11.36 & 9.00 & 2.92 & 11.92 & $97.4 \%$ & $88.7 \%$ & $95.3 \%$ \\
\hline
\end{tabular}

In 1991, 47\% (49\% in 1995) of installed capacity was held by public sector units. The private sector accounted for $36 \%$ (35\% in 1995) and the co-operative sector for only $17 \%$ (16\% in 1995).(Table 2.4; CMIE, 1996) Production shares are distributed slightly differently, due to sector specific capacity utilization and efficiencies. Public units have lower capacity utilization (Table 2.4). While most of the nitrogenous fertilizer production capacity can be found in the public sector, phosphatic fertilizer capacity is mainly installed in the private sector. 
Table 2.4: Fertilizer Production, Capacity and Capacity

Utilization by Sector (1991) (million tonnes of nutrients)

\begin{tabular}{|l|ccc|}
\hline & Production & Capacity & Capacity \\
& & & Utilization \\
\hline Nitrogen (N) & 7.30 & 8.21 & $89.0 \%$ \\
Share in N: & & & \\
Public Sector & $41.4 \%$ & $52.9 \%$ & $69.6 \%$ \\
Private Sector & $35.1 \%$ & $28.5 \%$ & $109.4 \%$ \\
Coop. Sector & $23.7 \%$ & $18.6 \%$ & $113.1 \%$ \\
\hline Phosphate (P) & 2.56 & 2.77 & $92.4 \%$ \\
Share in P: & & & \\
Public Sector & $28.5 \%$ & $28.9 \%$ & $91.3 \%$ \\
Private Sector & $57.8 \%$ & $59.9 \%$ & $89.2 \%$ \\
Coop. Sector & $13.7 \%$ & $11.2 \%$ & $112.9 \%$ \\
\hline Total & 9.86 & 10.98 & $89.8 \%$ \\
Share in Total: & & & \\
Public Sector & $38.0 \%$ & $46.8 \%$ & $73.0 \%$ \\
Private Sector & $41.0 \%$ & $36.4 \%$ & $101.0 \%$ \\
Coop. Sector & $21.1 \%$ & $16.8 \%$ & $113.0 \%$ \\
\hline \multicolumn{2}{|l}{} \\
\hline
\end{tabular}

For nitrogenous fertilizer capacity the share of the public sector has been declining over time. In as early as $1960-61$ the public sector accounted for $87 \%$ of nitrogenous fertilizer capacity. The private sector held a share of $13 \%$ and the co-operative sector did not exist yet. With the introduction of co-operative units and policy changes towards greater investment in the private sector (induced by a system of retention prices) in 1977, the share of the public sector started to decline and that of the private and co-operative sector to improve. Regarding phosphatic fertilizer production, throughout the years, the private sector has always enjoyed the highest share of up to $64 \%$. (Mittal, 1994)

Today, the cooperative sector assumes a major role within the fertilizer industry not only in fertilizer distribution but also in the provision of other general services to farmers such as credit programs, capital management, training schedules, etc. Around $97 \%$ of the villages and $45 \%$ of the rural population are participating in cooperative systems.

As can be seen in Table 2.5 about $88 \%$ of nitrogen nutrient come from straight nitrogenous fertilizer products, mainly from urea. The remaining share is covered through the use of complex fertilizer such as DAP and others. Phosphates are drawn from straight phosphatic fertilizers to only $28 \%$. The main share is supplied by complex NP/NPK fertilizers. The role of organic manure (green fertilizer) as a substitute and/or complement to chemical fertilizers has not yet found much consideration. Cow dung is widely used as fuel in rural areas, while further useful excrements from cattle as well as compost from urban waste, from forest litter and other waste materials are not utilized at all. 
Table 2.5: Share of Fertilizer Products in Total Nutrient Production (1990-91)

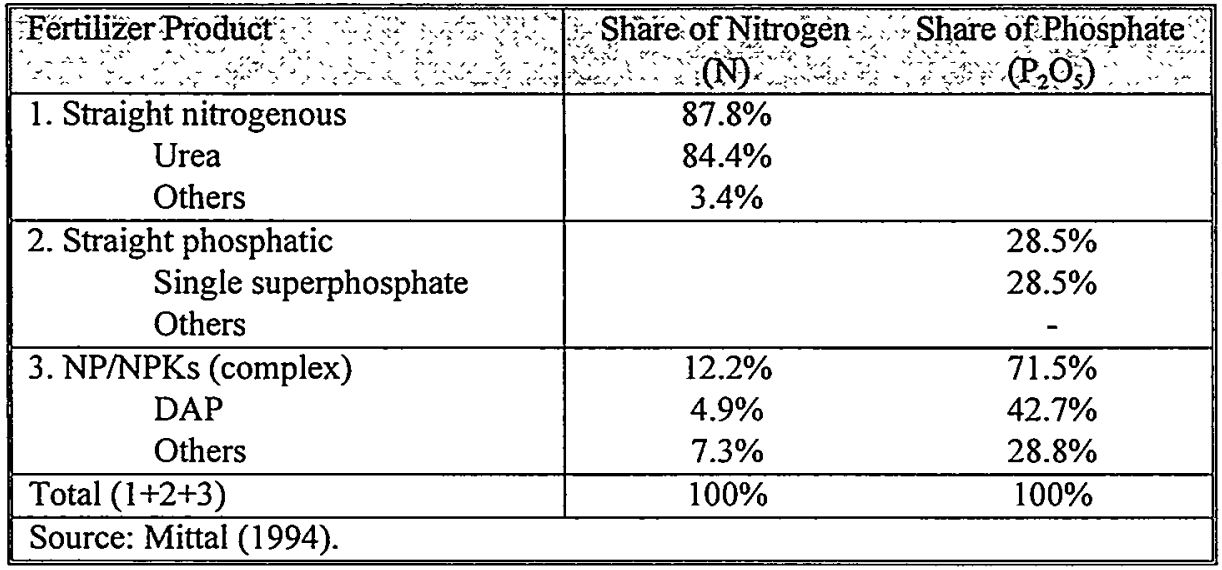

Although the Indian fertilizer sector progressed considerably over the past, there are various problems associated with the sector. These problems mainly relate to investment into capacity upgradation and expansion, to profitability of operation, and to availability, storage and transportation of raw materials and finished products. Investment projects have been very slow in the past. The delay in setting up fertilizer plants after the issue of the letter of intent can be up to 8-9 years. This increases the cost of projects considerably contributing to the continuous problem of capital scarcity. Major investment would need to be brought in from abroad to meet the capital requirements. The government of India granted concessions to attract foreign capital inflow for the fertilizer industry, such as majority equity participation, distribution rights etc. However, due to uncertainties surrounding the availability of raw materials in India as well as the high profitability of exports to India, the reaction to these concessions was very low. Capital remained scarce.

Particularly following the oil price shock, costs of inputs to fertilizer production, especially for energy as the single main input, were exceptionally high. Moreover, although the government promoted the setting up of fertilizer plants in dispersed areas to best possible serve local needs, constraints in transportation and storage of fertilizer still hit the industry. Availability of storage and transportation capacity was constrained among other reasons due to shortage in wagons for rail transportation, high demand for transportation by other sectors, storage capacity, quality and management of stored products.

\subsubsection{Raw Materials}

Domestic raw materials are available only for nitrogenous fertilizers. For the production of urea and other ammonia based fertilizers methane presents the major input which is gained from natural gas/associated gas, naphtha, fuel oil, low sulfur heavy stock (LSHS) and coal. In the more recent past, production has more and more switched over to the use of natural gas, associated gas and naphtha as feedstock. Out of these, gas is most hydrogen rich and easiest to process due to its light weight and fair abundance within the country. However, demand for gas is quite competitive since it serves as a major input to 
electricity generation and provides the preferred fuel input to many other industrial processes.

For production of phosphatic fertilizer most raw materials have to be imported. India has no source of elemental sulfur, phosphoric acid and rock phosphate. Yet, some low grade rock phosphate is domestically mined and made available to rather small scale single super phosphate fertilizer producers. Sulfur is produced as a by-product by some of the petroleum and steel industries.

\subsubsection{Energy Use}

Fertilizer production is one of the most energy intensive processes in the Indian industry. Energy is consumed in the form of natural gas, associated gas, naphtha, fuel oil, low sulfur heavy stock and coal. The choice of the feedstock is dependent on the availability of feedstock and the plant location. It is generally assigned to the plants by the government.

Production of ammonia has greatest impact on energy use in fertilizer production. It accounts for $80 \%$ of the energy consumption for nitrogenous fertilizer. The feedstock mix used for ammonia production has changed over the past. Since new capacity in the form of gas based fertilizer plants was added in the 1980s the share of gas has increased substantially. In 1992-93, the shares of feedstocks in ammonia production were: $54.2 \%$ natural gas, $26.1 \%$ naphtha, $18.2 \%$ fuel oil, and $1.5 \%$ coal (TERI, 1996) while, in 198182, it was: $52 \%$ naphtha, $19 \%$ fuel oil, $19 \%$ coke oven gas and $10 \%$ coal (Kalra, 1989). The shift towards the increased use of natural/associated gas and naphtha is beneficial in that these feedstocks are more efficient and less polluting than heavy fuels like fuel oil and coal. Furthermore, capacity utilization in gas based plants is generally higher than in other plants. Therefore, gas and naphtha present the preferred feedstocks for nitrogenous fertilizer production.

Energy intensity in India's fertilizer plants has decreased over time. This decrease is due to advances in process technology and catalysts, better stream sizes of urea plants and increased capacity utilization. Capacity utilization is important as losses and waste heat are of about the same magnitude no matter how much is actually produced in a plant at a specific point of time. The evolution of specific energy consumption on average and by feedstock is shown in Table 2.6. Since ammonia production holds the highest share of energy consumption, the numbers given here are for energy intensity in ammonia plants. Actual energy consumption in a plant depends on the age of the technology and the scale of the plant. For example, a typical ammonia plant established in 1970s would be a 600 tpd gas based process with an efficiency of 9.8 to $10.2 \mathrm{Gcal} / \mathrm{Mt}$. A plant established in early 1990 s would consume only 8.0 to $8.5 \mathrm{Gcal} / \mathrm{Mt}$. (Trivedi, 1998)

The production of phosphatic fertilizer requires much less energy than nitrogenous fertilizer. Depending on the fertilizer product, in 1993-94, energy consumption varied from negative input for sulfuric acid to around $1.64 \mathrm{GJ} /$ tonne of fertilizer for phosphoric 
acid (TERI, 1996). For sulfuric acid the energy input is negative since more steam (in energy equivalents) is generated in waste heat boilers than is needed as an input.

Table 2.6: Specific Final Energy Consumption of Ammonia Plants: Average and by Feedstock (Gcal/Mt of ammonia)

\begin{tabular}{|c|c|c|c|c|c|c|c|c|c|}
\hline Feedstock $:$, & $\begin{array}{l}1979- \\
80\end{array}$ & $\begin{array}{r}1983= \\
84\end{array}$ & $\begin{array}{c}1986 \\
87\end{array}$ & $\begin{array}{l}1988= \\
89\end{array}$ & 92 & $\begin{array}{l}1992- \\
93 \\
93\end{array}$ & $\begin{array}{l}1993- \\
94\end{array}$ & $\begin{array}{l}1994- \\
95\end{array}$ & $\begin{array}{r}1995 \\
96\end{array}$ \\
\hline Gas & na & na & na & 10.0 & 9.6 & 9.5 & 9.36 & 9.26 & na \\
\hline Naphtha & na & na & na & 12.2 & 11.7 & 11.7 & 11.5 & 11.3 & na \\
\hline Fuel Oil & na & na & na & 14.3 & 13.5 & 13.9 & $14.2^{\mathrm{a}}$ & $14.3^{\mathrm{a}}$ & na \\
\hline Coal & na & na & na & 33.8 & 39.7 & 42.7 & 39.7 & na & na \\
\hline Average & 14.8 & 14.0 & 13.4 & 11.9 & 11.6 & 11.4 & 11.5 & 11.0 & 10.9 \\
\hline
\end{tabular}

\subsection{Past and Future Demand}

Fertilizer consumption depends on various factors. These include agricultural related factors such as geographical aspects, calamities, rainfall and irrigation patterns, soil quality, farming methods, availability of technology and information, varieties and qualities of seeds as well as access to capital and other inputs. Additionally, fertilizer consumption depends on more macro oriented factors such as market forces and policies regarding demand and supply.

The introduction of high yielding varieties of seeds and the greater awareness of the benefits of fertilizers - spread out through government initiated extension networks that started in the 1960s - significantly spurred the production and consumption of fertilizers. As shown in Table 2.7 fertilizer consumption more than doubled between 1980 and 1990 . Imports during the same time period did not increase. Rising consumption could entirely be met by increases in production. The increase in consumption and production in the 1980s was made possible to a large extent by tremendous subsidies provided by the government. Between 1980 and 1990 subsidies to fertilizer production increased more than eightfold. From 1990 on, consumption as well as imports of fertilizer increased again accompanied by a further increase of subsidies. However, the consumption of phosphatic fertilizers which can not be produced domestically remained rather stagnant.

The optimal mix of fertilizer components depends on the variety of seeds to be grown and the soil quality specific to the region. To assure more efficient use of fertilizer the government has promoted the setting up of soil testing laboratories throughout the country. However, more recently in the progress of liberalization, industry policy and subsidy schemes moved towards supporting nitrogenous fertilizers relatively more than phosphatic and potassic fertilizers. (Prasad et al., 1994; Subbiah, 1994) This has led to a shift in the consumption of nutrients away from a generalized ideal fertilizer balance of 4:2:1 NPK to a ratio of 5.9:2.4:1 NPK in 1991-92 and further to 8.5:2.5:1 NPK in 199596 reducing the economic and ecological productivity of fertilizer substantially. 
Demand projections for fertilizer consumption up to the year 2001-02 are presented in Table 2.8. Due to continued increase in population and food requirements, demand for fertilizer is expected to further grow at a optimistically stable mix of nutrients $(6.8: 2.1: 1$ NPK). This will help to substantiate agricultural growth.

Table 2.7: Fertilizer Consumption, Imports and Subsidies

\begin{tabular}{|c|c|c|c|}
\hline Year & $\begin{array}{l}\text { Consumption } \\
\text { (million tonnes) }\end{array}$ & $\begin{array}{l}\text { Imports } \\
\text { (million tonne }\end{array}$ & $\begin{array}{l}\text { Subsidies } \\
\text { Rs.million) }\end{array}$ \\
\hline $1970-71$ & 2.26 & 0.63 & na \\
\hline $1980-81$ & 5.52 & 2.76 & 5,050 \\
\hline 1990-91 & 12.55 & $2.76(1.33)$ & 43,890 \\
\hline 1991-92 & 12.73 & $2.77(1.24)$ & 48,000 \\
\hline $1992-93$ & 12.16 & $2.98(0.86)$ & 57,960 \\
\hline 1993-94 & 12.37 & $3.17(1.28)$ & 43,990 \\
\hline $1994-95$ & 13.83 & 3.12 & 52,410 \\
\hline $1995-96$ & na & na & 62,350 \\
\hline $1996-97$ & na & na & 60,930 \\
\hline \multicolumn{4}{|c|}{ Source: Center for Monitoring the Indian Economy (1996). } \\
\hline
\end{tabular}

Table 2.8: Demand Projections - Fertilizer

(million tonnes of nutrients)

\begin{tabular}{|l|cccc|}
\hline Year & Nitrogen $(\mathrm{N})$ & Phosphate $\left(\mathrm{P}_{-2} \mathrm{O}_{5}\right)$ & Potassium $\left(\mathrm{K}_{2} \mathrm{O}\right)$ & Total \\
\hline $1997-1998$ & 11.0 & 3.46 & 1.55 & 16.01 \\
$1998-1999$ & 11.4 & 3.56 & 1.65 & 16.60 \\
$1999-2000$ & 11.7 & 3.64 & 1.72 & 17.10 \\
$2000-2001$ & 12.1 & 3.71 & 1.77 & 17.57 \\
$2001-2002$ & 12.4 & 3.77 & 1.82 & 18.03 \\
\hline AAGrowth & & & & $3.0 \%$ \\
\hline
\end{tabular}

${ }^{\mathrm{A} A A G r o w t h ~-~ a v e r a g e ~ a n n u a l ~ g r o w t h ~ r a t e ~ c a l c u l a t e d ~ a s ~ c o m p o u n d ~ g r o w t h . ~ . ~}$

\subsection{Policy}

The Indian fertilizer sector has been under strict government control for most of the period since independence. A price and distribution control system was considered to be necessary not only to ensure fair prices and equal distribution all over the country but also to provide incentives for more intensive use of fertilizers. A control system of licensing and approval of collaboration aimed at standardizing technology and capacity of plants. The goal of government intervention was to improve agricultural productivity and thus the basic supply of food

Until 1970, only straight nitrogenous fertilizers were under price control and no general distribution control was practiced. In October 1970, Indian fertilizer policy was completely reviewed and controls on prices and distribution of fertilizer reintroduced, reinforced or revised. A control on fertilizer distribution was reintroduced in 1973 (Fertilizer Movement Control Order) due to shortages of supply in various areas. The movement of fertilizer was subject to the 'Essential Commodity Act' (ECA). Percentages 
and types of fertilizer under control of ECA varied over time depending on the actual demand and supply requirements.

The price control that had earlier been introduced for four nitrogenous fertilizers was supposed to cover the costs of individual fertilizer plants and the capacity of the cultivator to bear the price burden. Therefore, a common controlled price for each type of fertilizer whether indigenously produced or imported was adopted. However, the retention prices to different plants in public and private sectors varied, depending on their cost differential. Prices were paid to a "Common Fertilizer Pool". Out of this pool different prices were paid to individual manufacturers and for imports. (Mittal, 1994)

Under the control system units were obliged to use specific types of feedstock assigned by the government on the basis of the location of the plant and the availability of feedstock. The choice of feedstock presents an important factor for the capital and operating costs of a plant. Total cost of production for nitrogenous fertilizers is lowest for plants based on natural gas or naphtha, substantially higher for fuel oil based plants and highest for coal based plants. Since feedstocks were assigned, plants produced at very different costs of production for reasons not internal to the plants or to the efficiency of their operations. Therefore individual retention prices differed substantially.

Although retention prices were individually based on normative costs and included a specific return on investment plants, mostly public sector plants, suffered from losses due to higher actual costs. High costs were due to lower than anticipated capacity utilization and increases in the prices of raw materials. The oil price shock in 1973 led to tremendous price increases for imported fertilizers. Additionally, import prices for oil and naphtha rose thus leading to higher indigenous costs of fertilizer production. Consequently, in 1974, the government of India introduced the Fertilizer Pool Equalization Charge (FPEC). Indigenous manufacturers were required to contribute a specific amount, Rs. 610 per tonne of urea, into this pool which was used to subsidize the cost of imported fertilizers.

Nevertheless, the fertilizer industry suffered following the oil price shock. Cost increases in the production and import of fertilizer led to a slowing of investment into new capacity. In order to ensure sufficient use of fertilizer at reasonable prices and to stimulate investment, in January 1976, the government set up a committee (Marathe Committee) to revise and improve the pricing system. The major goals of the study conducted by the committee included the establishment of norms for determining the production costs for individual units, the rationalization of prices of feedstocks and other inputs, the revision of ex-factory realization from time to time due to any change in cost of inputs, and the development of a pricing policy of imported fertilizers.

The committee recommended a 12 percent post tax return on net worth (regardless of the location, age, technology and cost of production) and fixed a retention price for each unit according to the costs of production. The computation of cost was based on the assumption of $80 \%$ capacity utilization (for ammonia-urea plants) coupled with 
consumption norms of raw materials, energy etc. These numbers were fixed with the view of enhancing capacity utilization, promoting efficiency of existing plants as well as stimulating investment into new capacity. The system was to be applied to all manufacturers whether in the public, private or cooperative sector.

In 1977, nitrogenous fertilizers were put under the new scheme of retention prices involving subsidization as recommended by the committee. According to the nature of the scheme, subsidies were higher for high cost units and lower for low cost units. Controlled selling prices of fertilizers were not disturbed. The retention price scheme encouraged fertilizer consumption through low subsidized farm gate fertilizer prices and on the other hand encouraged production of fertilizer through ensuring adequate returns to producers. The system was originally thought to be self financing. However, low consumer prices, rising input costs, increased output and high capital costs of production resulted in an escalating need for additional governmental subsidies to sustain the system.

The system of freight equalization was applied to the fertilizer industry to ensure supply of fertilizer at uniform prices throughout the whole country. Further subsidies to the fertilizer industry were given to support fertilizer use in backward, hilly, inaccessible and tribal areas and by small and marginal farmers in dry areas. In view of these subsidies retail prices could be reduced between 1974 and 1979 and remained stable thereafter for the decade of the 1980s. Due to mounting subsidies and rising profits of fertilizer companies the government tightened the norms on capacity utilization and depreciation to reduce retention prices and thus subsidies. In January 1989 with retrospect to April 1988, capacity utilization norms were increased to $90 \%$ for gas-based urea plants and $85 \%$ for naphtha and fuel oil based plants. Depreciation was based on 20 year lifetime instead of 10. Capacity utilization norms were set slightly lower from the $11^{\text {th }}$ year of plant lifetime onwards: $85 \%$ for gas-based urea plants and $80 \%$ for naphtha and fuel oil based plants. Coal based plants were subject to a norm of $60 \%$ capacity utilization for the first 10 years and $55 \%$ thereafter, phosphoric acid plants' norms were $75 \%$ and $70 \%$ respectively.

In addition, substantially increasing stocks of fertilizer in the 1980 s gave way to consider abandoning the distribution control system under ECA and introducing a system of free distribution under the retention price subsidy and a normative transport allowance. The goal of exempting large quantities of fertilizer from allocation control was to increase competitiveness among producers and bring down prices as well as to reduce subsidies on transportation. The government partially eased distribution of fertilizers in 1987 and 1988. Specific quotas not covered by ECA were allowed to be freely distributed. However, for these quantities the system of freight equalization would not apply with the effect that extra freight cost involved above the normal freight under ECA allocation would not be reimbursed.

This following and unlike most other sectors, the industry started resisting against governmental steps towards liberalization of the sector. Abandoning or reducing allocation controls of fertilizer, they feared, would diminish fertilizer use, impede agricultural progress and suspend growth of the fertilizer industry. Furthermore, fertilizer 
manufacturers would have to transport their products to wherever demand exists including remote and inaccessible areas. This would place further burden on the overall strained transport system and generate additional production costs not compensated by the government.

In order to further reduce subsidies the government decided in July 1991 to increase fertilizer prices for farmers by $40 \%$. However, as a result of immense pressure by various lobbies, in August 1991, the government reduced the price increase to $30 \%$ for big farmers and withdrew it for small and marginal farmers. Since the system of dual pricing included lower prices for small and marginal farmers and higher prices for big farmers many large farmers started splitting up their holdings into smaller entities to qualify for the lower prices.

Following this and the devaluation of the rupee in 1991 subsidies to the industry mounted. Of all subsidies distributed by the government the fertilizer industry received more than two-fifth in 1991-92. Moreover, the industry enjoyed much higher subsidies because of additionally benefits from indirect subsidies through the system of differential pricing.

As a consequence of increasing budget deficits a system of partial decontrol was introduced effective August 1992. Prices, distribution and movement (freight equalization) was completely decontrolled for phosphatic and potassic fertilizers. However, to further ensure and promote the dispersed use of nitrogenous fertilizers, urea continued to remain under price control. Its price was reduced by $10 \%$. Low analysis nitrogenous fertilizers which had been decontrolled in July 1991 were brought back under control. Additionally, the government decided to adjust foodgrain procurement prices to account for the changes in fertilizer prices.

Immediately following the decontrol of phosphatic and potassic fertilizers prices went up sharply $(70-100 \%)$ and temporary shortages occurred. As a neutralization measure the government announced (i) the exemption of phosphoric acid from custom duty when imported for use in fertilizer production, (ii) the exemption of $15 \%$ basic duty on import of fertilizer projects under a specific import scheme, (iii) the permission to import raw materials at official exchange rates etc. However, these measures did not result in sufficient reduction of fertilizer (particularly DAP) prices. The government had to provide further subsidies. It became apparent that higher fertilizer prices result in reduced input use and lower production. Any price adjustment would therefore need to include a mechanism that compensates farmers for their increased production costs by ensuring higher product prices. With the decontrol of low analysis nitrogenous fertilizers in June 1994 today all fertilizers except urea have become free of controls. (Datt et al. 1998; Mittal, 1994; Basu et al., 1994; Singh et al., 1994 and Ahluwalia 1985, 1991) 
Table 2.9: Overview of Policies Regarding the Fertilizer Industry

\begin{tabular}{|c|c|c|}
\hline Period & \multicolumn{2}{|c|}{ Policy } \\
\hline 1957 & Fertilizer Control Order & Price and Distribution Control \\
\hline Before 1970 & Price Control & $\begin{array}{l}\text { Control of straight nitrogenous fertilizers including urea, } \\
\text { ammonium sulfate and CAN (1966), no or irregular price controls of } \\
\text { other fertilizers }\end{array}$ \\
\hline & Distribution Control & $\begin{array}{l}\text { Gradual decrease of distribution control, no area-wise price and } \\
\text { distribution control (ceiling price only) since } 1968\end{array}$ \\
\hline Oct. 1970 & Review of Fertilizer Policy & \\
\hline Around 1970 & Common Fertilizer Pool & $\begin{array}{l}\text { Pool used to account for individual cost structure of plants (different } \\
\text { retention prices) }\end{array}$ \\
\hline 1973 & $\begin{array}{l}\text { Re-Introduction of } \\
\text { Distribution Control }\end{array}$ & $\begin{array}{l}\text { Fertiliser Movement Control Order, Essential Commodity Act } \\
\text { (ECA): Percentage fertilizer under ECA varied from time to time }\end{array}$ \\
\hline 1974 & $\begin{array}{l}\text { Fertilizer Pool Equalization } \\
\text { Charge (FPEC) }\end{array}$ & $\begin{array}{l}\text { Additional charge to pool used to subsidize high costs of imported } \\
\text { fertilizer following oil price shock }\end{array}$ \\
\hline January 1976 & $\begin{array}{l}\text { High Power Fertilizer } \\
\text { Prices Committee }\end{array}$ & $\begin{array}{l}\text { Develop suitable price system: Ensuring higher fertilizer use, } \\
\text { financial health and growth of the industry }\end{array}$ \\
\hline 1977 & Review of Price Control & $\begin{array}{l}\text { Review of price control for nitrogenous fertilizers based on the } \\
\text { recommendations of the committee }\end{array}$ \\
\hline 1977 & Retention Price System. & Introduction of retention price system for nitrogenous fertilizers \\
\hline Feb. 1979 & Price Control & $\begin{array}{l}\text { Retention price system (RPS) for phosphatic fertilizers such as DAP } \\
\text { and other complex fertilizers (NP and NPK) }\end{array}$ \\
\hline June 1980 & Price Decontrol & $\begin{array}{l}\text { Price Decontrol of low analysis nitrogenous fertilizers (AS, CAN, } \\
\text { ACI) }\end{array}$ \\
\hline May 1982 & Price Control & Retention price system for Single Superphosphate (SSP) \\
\hline September 1984 & Price Control & Price control again for low analysis nitrogenous fertilizers \\
\hline $1987-88$ & $\begin{array}{l}\text { Free Allocation of Specific } \\
\text { Quantities of Fertilizer for } \\
\text { Rabi (1987-88) and Kharif } \\
\text { (1988) }\end{array}$ & $\begin{array}{l}\text { Free movement of quantities of single super phosphate (SSP) and } \\
\text { complex fertilizers not covered by the ECA - No reimbursement of } \\
\text { extra freight cost involved over and above the normal freight under } \\
\text { ECA allocation. }\end{array}$ \\
\hline April 1988 & Revision of Price Control & Reduction of retention prices and subsidies for nitrogenous fertilizer \\
\hline July 1991 & Price Decontrol & Price decontrol of low analysis nitrogenous fertilizers \\
\hline August 1991 & Dual Pricing Policy & $\begin{array}{l}30 \% \text { price increases of fertilizer for big farmers, no price increase } \\
\text { for small and marginal farmers }\end{array}$ \\
\hline August 1992 & Partial Decontrol & $\begin{array}{l}\text { Decontrol of prices, distribution and movement of phosphatic and } \\
\text { potassic fertilizer, recontrol of low analysis nitrogenous fertilizers, } \\
10 \% \text { price reduction for urea fertilizer }\end{array}$ \\
\hline $\begin{array}{l}1992 \text { until } \\
\text { March } 1993\end{array}$ & Subsidy & Subsidies on DAP, NP, NPK fertilizers \\
\hline September 1992 & Import Liberalization & $\begin{array}{l}\text { Import of raw material for manufacture of DAP and other complex } \\
\text { phosphatic fertilizers (not SSP) allowed at lower official exchange } \\
\text { rate (under dual exchange system) with no customs duty }\end{array}$ \\
\hline 1993 & Subsidy & $\begin{array}{l}\text { Continuation of subsidies on domestic phosphatic fertilizers, } \\
\text { introduction of subsidies on SSP }\end{array}$ \\
\hline June 1994 & $\begin{array}{l}\text { Decontrol } \\
\text { Price Increase }\end{array}$ & $\begin{array}{l}\text { Decontrol of low analysis nitrogenous fertilizers again } \\
\text { Urea prices raised by } 20 \%\end{array}$ \\
\hline
\end{tabular}




\section{Statistical and Econometric Estimates}

\subsection{Statistical Analysis}

A variety of studies on productivity growth and technological change in Indian industries has been carried out so far. Originally these studies were driven by an interest in understanding the capital vanishing phenomena in the Indian industry between 1950 and 1980. During that time labor productivity as well as capital availability and use increased considerably, while the overall growth rate of the economy, however, stagnated at low levels (see Ahluwalia, 1991). Concerned about the efficiency of resource use researchers started investigating productivity growth and input factor substitutions for aggregate manufacturing as well as various industries. The results of these analyses differed substantially depending on the methodology, statistical specification employed as well as on the underlying sources of data, levels of aggregation and time periods considered.

Over time more sophisticated and refined methodologies in connection with longer time series were employed to study productivity change. The contribution of total factor productivity to output growth was of primary interest to explain the still low economic development. Partial factor productivity was investigated to better understand the importance of each factor of production and to evaluate substitution possibilities. In this context the role of energy within the production process received increasing attention and consequently besides the primary factors of production (capital and labor), energy and materials were added as secondary input factors into the analyses.

Commonly, three major growth accounting approaches are considered for estimating total factor productivity as well as total productivity growth: the Translog Index, the Solow Index and the Kendrick Index. Total factor productivity growth (TFPG) measures the growth in gross value added (GVA) in excess of the growth of a weighted combination of the two inputs capital and labor. For measuring output in form of gross value added all intermediate inputs are deducted. Thus, gross value added only provides the value that is actually added in the production process by using the two primary inputs of production: capital and labor. Total Productivity Growth, in contrast, relates gross value of output (VO) to the four input factors capital, labor, energy and materials. Since it accounts for intermediate inputs as well as primary inputs, value of output provides the more appropriate output measure if interested in analyzing energy and material as well as capital and labor.

The three indices developed differ in their complexity and the underlying economic assumptions. A detailed derivation of the three indices is provided in a survey report by Mongia and Sathaye (1998a). The Kendrick index is easy to understand in using an arithmetic aggregation scheme for the inputs. It is restrictive in that it is based on the assumption of a linear production function and in assigning constant (base year) shares in GVA (VO respectively) to the inputs. The Solow index is slightly more general in assuming a neo-classical, Cobb-Douglas, specification of the production function with constant returns to scale, perfect competition in the market and factors being rewarded 
their marginal products. The translog measure is based on a more complex production function associated with only a minimum numbers of assumptions. It is therefore of more general nature and provides the preferably used measure for productivity growth.

Partial factor productivity (PP) indices are reported for all input factors. They are obtained by simply dividing the value figure for each factor by the gross value of output or by the gross value added respectively. Partial factor productivity growth indicates how much output changes in relation to a fixed amount of each single input. It measures how "productive" a factor is. Taking the inverse it means how much of a factor has to be used to produce a specific amount of output - it measures the factor intensity of production. Changes over time indicate a shift in production towards more intensive use of one factor probably accompanied by less use of another factor. Additionally, the capital labor ratio (K-L ratio) shows how much capital per head is used in the production process and provides a rough measure of the capital intensity of production. The tradeoff between capital and labor is particularly interesting in the context of labor intensive developing countries, like India, that decided on the emphasis of capital intensive industries in its early development stages in order to improve the overall economic situation.

Considering capital and labor productivity one should keep in mind that conceptually, in situations where capital intensity is increasing over time, the analysis of partial productivity changes may overstate the increase in labor productivity and understate the increase in capital productivity (Ahluwalia, 1991). With rising capital labor ratio resources may shift from labor to the use of capital. Due to this shift, the measured increase in labor productivity may be larger than the pure increase in the productivity component (i.e. the change that is solely due to learning, learning-by-doing, improvement of skills, experience etc.). Similarly, the increase in pure capital productivity may be higher than the measured increase.

The next section will give an overview of previous studies that have been conducted on productivity changes in the fertilizer industry. Thereafter, in the following section, we develop our own estimates for both total and partial productivity using a consistent theoretical and empirical framework.

\subsubsection{Previous Studies}

Previous results for statistical estimates of total factor productivity using the Translog, Solow and/or Kendrick index as well as measures of partial factor productivity and production functions for the fertilizer industry are given in Appendix A. Figures $3.1-3.4$ display both the historical as well as our own estimates graphically. The graphical presentation allows to immediately realize the large differences in the estimates obtained by researchers for various points of time. The overview draws on Mongia and Sathaye (1998a). 


\subsubsection{Partial Productivity}

\section{Capital Productivity}

Partial productivity growth estimates for capital are presented in Figure 3.2. As can be seen from the figure, estimates differ depending on the time period and range under consideration. All previous estimates reveal negative capital productivity change. Productivity loss for Arora is lowest at $-0.6 \%$ p.a. for the period 1973-81. Ahluwalia shows a slightly higher decline at $-1 \%$ p.a. for the period $1960-85$. Gupta conducted a study relying on primary plant level data of all chemical fertilizer plants commissioned before 1975 distinguishing public and private plants. For the period 1969-76, Gupta reveals a much higher decrease of capital productivity at $-9.3 \%$ p.a. for the private sector and $-5.6 \%$ p.a. for the public sector. Bansal's results are similar. Between 1986-94 capital productivity declined at $-3.1 \%$ p.a. in the public sector and at $-13.4 \%$ p.a. in the private sector.

\section{Labor Productivity}

Historical estimates for labor productivity as shown in Figure 3.3 range widely from positive to negative numbers. Ahluwalia estimates a significant increase in labor productivity at $6.3 \%$ p.a. for the years $1960-85$. Arora reports slightly lower productivity increase at 5.4\% p.a. (period 1973-81). Gupta and Bansal, however, report negative numbers for both the public and private sector. Labor productivity declines at $-3.3 \%$ p.a., $-2.2 \%$ p.a. respectively, for the public sector. An even stronger decline is observed in the private sector at $-6.2 \%$ p.a., $-4.8 \%$ respectively.

\section{Capital-Labor Ratio}

The overall trend in the fertilizer industry has been towards capital deepening as indicated by the development of the capital-labor ratio. All studies support this finding. Both, Ahluwalia and Bansal (private sector) conclude a considerable increase in the capital labor ratio of $7.5 \%$ p.a. between $1960-85$ and $8.6 \%$ p.a. between $1986-94$ respectively. Arora obtains a more moderate increase of $5.5 \%$ between 1973-81, while all other estimates are in the lower range of $0.9 \%$ p.a. to $3.2 \%$ p.a.

\section{Material Productivity}

Only few authors consider additional inputs and productivity changes in their investigations. Gupta includes material inputs in the productivity analysis and concludes very reverse results for the public and the private sector. A positive growth in material productivity of $3.9 \%$ p.a. can be found in the public sector between 1969-76. However, at the same time material productivity in the private sector fell by $-2.0 \%$ p.a.. 


\section{Figure 3.1: Estimates of Total Factor Productivity Growth}

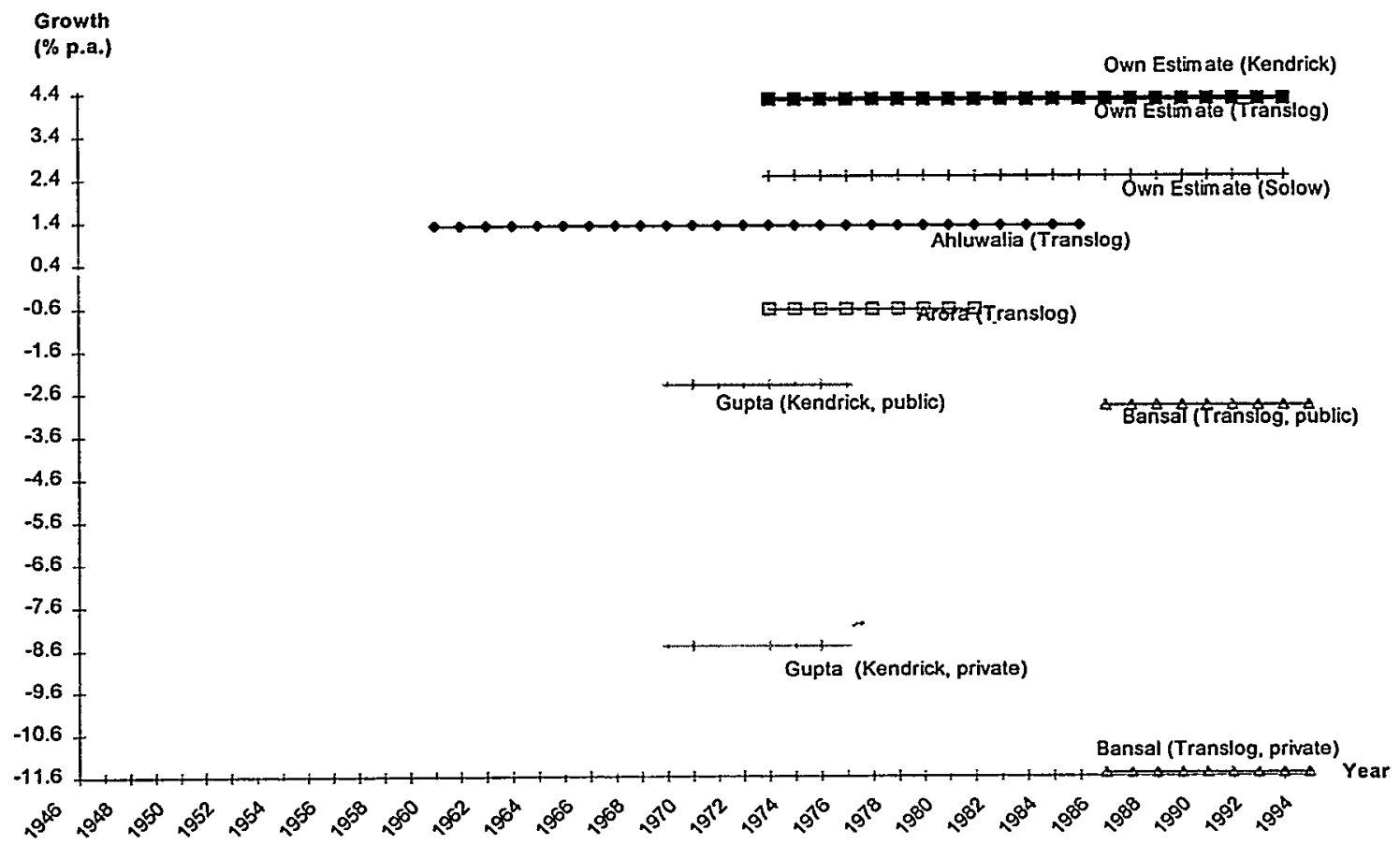

\section{Figure 3.2: Estimates of Partial Productivity Growth: Capital}

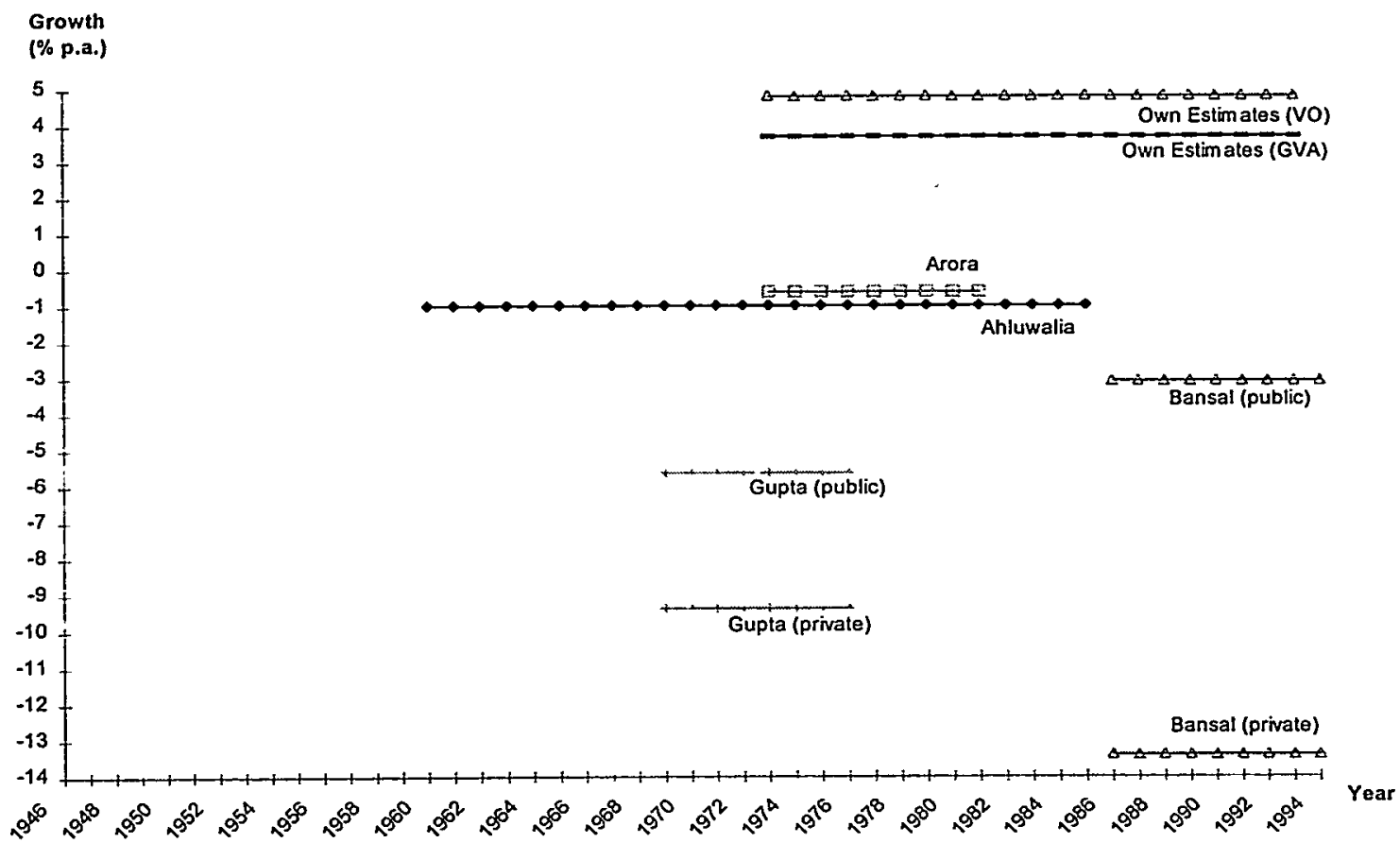


Figure 3.3: Estimates of Partial Productivity Growth: Labor

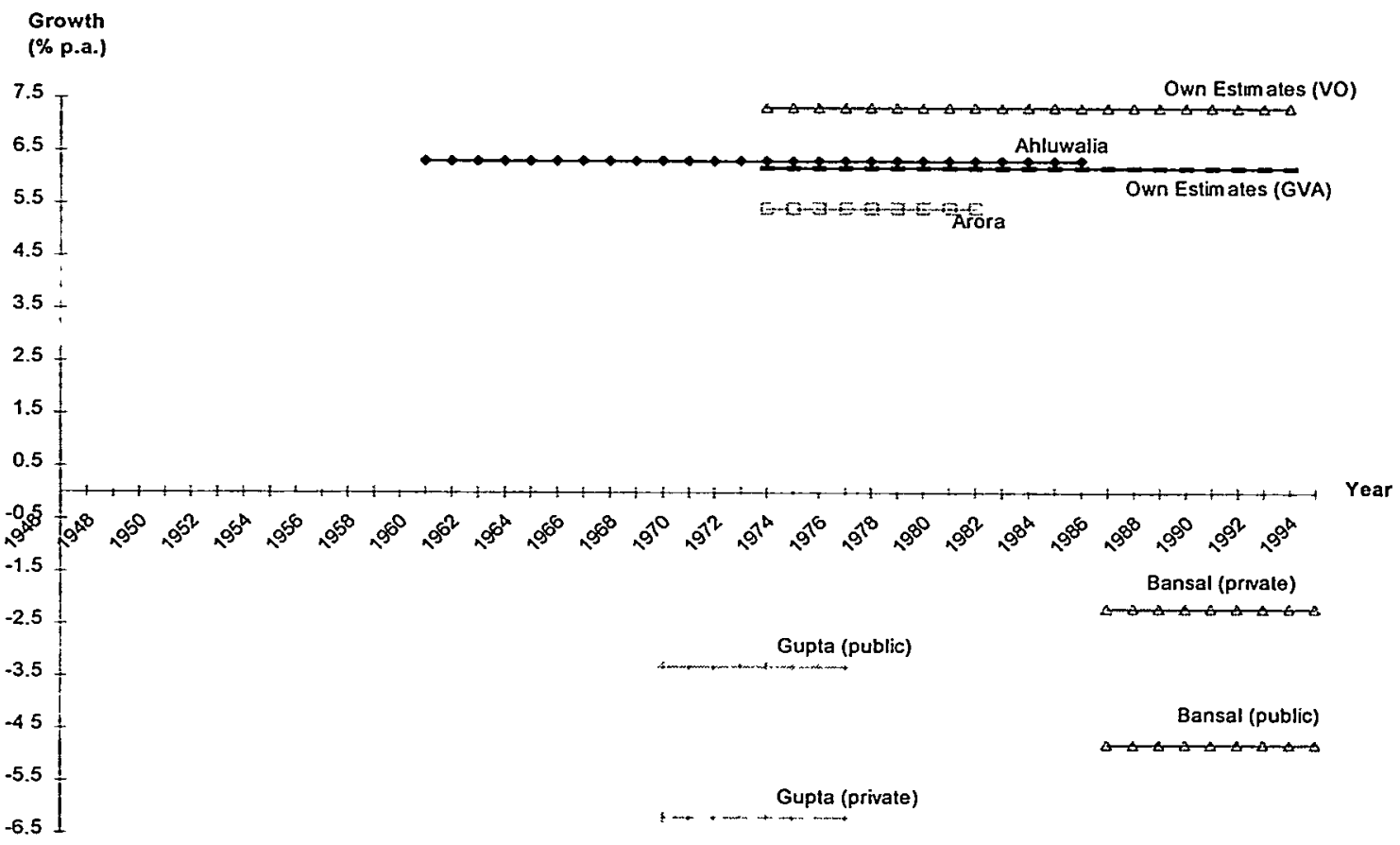

Figure 3.4: Estimates of Capital-Labor Ratio

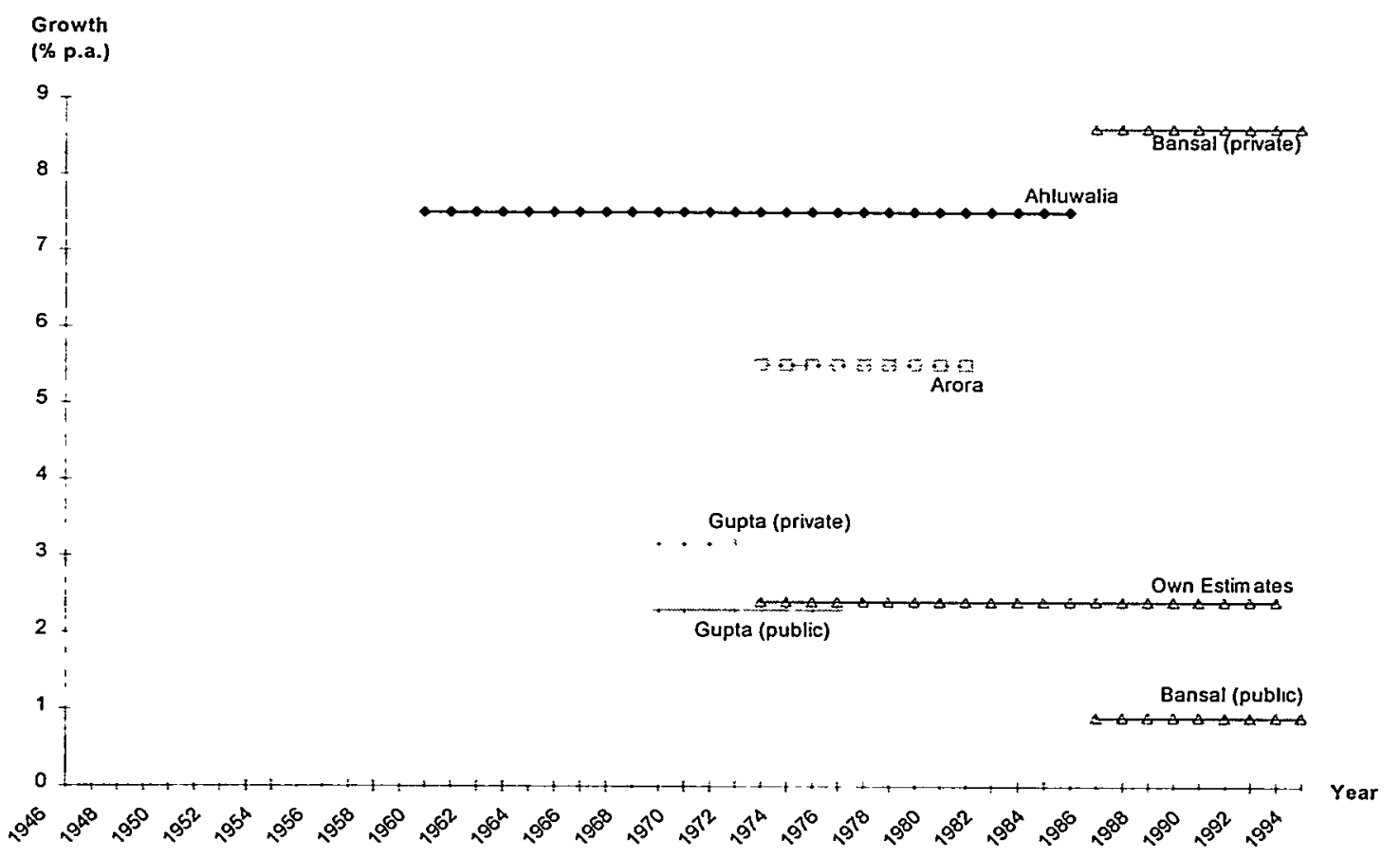

Note: "Own Estimates" are compound growth rates for the time period under consideration. For the translog indices they present exponential growth.

20 


\subsubsection{Total Factor Productivity Growth}

Total factor productivity in the fertilizer sector has been investigated in the same studies. Ahluwalia reports the only positive growth at an average $1.3 \%$ p.a. (translog index) for the period 1960-85. Arora as well as Gupta and Bansal reveal losses in productivity. While these are relatively low for Arora and the public sector analysis by Gupta and Bansal - ranging from $-0.7 \%$ p.a. to $-2.9 \%$ p.a. - the private sector analysis reveals a considerable decline at $-8.5 \%$ p.a. for the earlier period, $1969-76$ (Gupta), and $-11.5 \%$ p.a. for the later period, 1986-94 (Bansal).

\subsubsection{Own Estimates}

In this section we present in detail our own estimates for both total and partial productivity. We develop the Translog, Solow and Kendrick index using a consistent theoretical and empirical framework. With the recognition of energy as a critical factor for economic growth and the special emphasis on energy use within this report, we explicitly account for energy in using a four factor input approach $(K, L, E, M)$. As a comparison, we additionally state the results obtained from the two input factor model. Data has been compiled for the years 1973-93 from the Annual Survey of Industries, Government of India (various years). The methodology is explained in detail in Mongia and Sathaye (1998).

\subsubsection{Partial Productivity}

Table 3.1 gives partial productivity based on both value of output and gross value added. The table indicates the growth rate over the whole time period as well as split up by different time ranges within this period. Growth rates for the time periods are calculated as compound growth rates and time trends. This is to be in accordance with existing growth estimates conducted by various authors and presented in section 3.1.1. above. Figure 3.5 displays the partial productivity of capital, labor, energy and material in relation to the value of output.

Table 3.1: Partial Productivity Growth

(selected time periods, per cent p.a.)

\begin{tabular}{|l|ccccccc|}
\hline$\therefore$ & Capital & Labor & Energy & Mătérial & K/L ratio & Capital & Labor \\
Growth & Vo $/ \mathrm{K}$ & VO $/ \mathrm{L}$ & VO $/ \mathrm{E}$ & VO $/ \mathrm{M}$ & $\mathrm{K} / \mathrm{L}$ & GVA $/ \mathrm{K}$ & GVA $/ \mathrm{L}$ \\
\hline $1973-93$ & 4.80 & 7.32 & 1.86 & 0.77 & 2.40 & 3.68 & 6.17 \\
$1973-79$ & 4.68 & 8.45 & 2.00 & 3.43 & 3.61 & -1.04 & 2.52 \\
$1979-91$ & 8.53 & 10.94 & 2.89 & 0.36 & 2.22 & 7.70 & 10.09 \\
$1991-93$ & -14.73 & -14.79 & -4.52 & -4.55 & -0.07 & -5.06 & -5.13 \\
\hline Trend Rate & & & & & & & \\
$1973-93$ & 7.21 & 8.97 & 2.57 & 1.89 & 1.76 & 6.19 & 7.94 \\
\hline
\end{tabular}

Note: Compound Growth; Trend Rate calculated as semi-logarithmic time trend, significant on 5\% level.

Over the whole time period (1973-93) all factor productivities show an increasing trend. The growth rates as well as the figure support changes in average productivity in the late 1970 s and again in the early 1990s. Generally, labor and capital follow very similar 
patterns as do energy and material. Between 1973 and 1979, all input factor productivities show progress although for the years 1973-75/76 a downward trend can be observed. From 1979 until 1990/91, labor and capital productivity advance with slight fluctuations at high rates. Labor productivity gains are highest at an average $10.94 \%$ p.a. during that period followed by $8.53 \%$ p.a. growth in capital productivity. A small local peak in both capital and labor productivity can be observed in 1984. In contrast, material and energy productivity do not show such a clear upward move for the period 1979-1990/91. Until $1986 / 87$, energy as well as material productivity remains quite stable only increasing thereafter. Growth in material productivity is lowest at $0.36 \%$ p.a. between $1979-91$, while energy productivity increases at an average $2.89 \%$ p.a. A sharp turnaround in productivity development takes place in 1990/91. The period beginning 1990/91 exerts a significant cut in productivity for all input factors, particularly for capital and labor ($14.73 \%$ p.a. and $-14.79 \%$ p.a. respectively).

\section{Figure 3.5: Index of Partial Productivity (KLEM and Value of Output)}

based on 1973-74 constant values

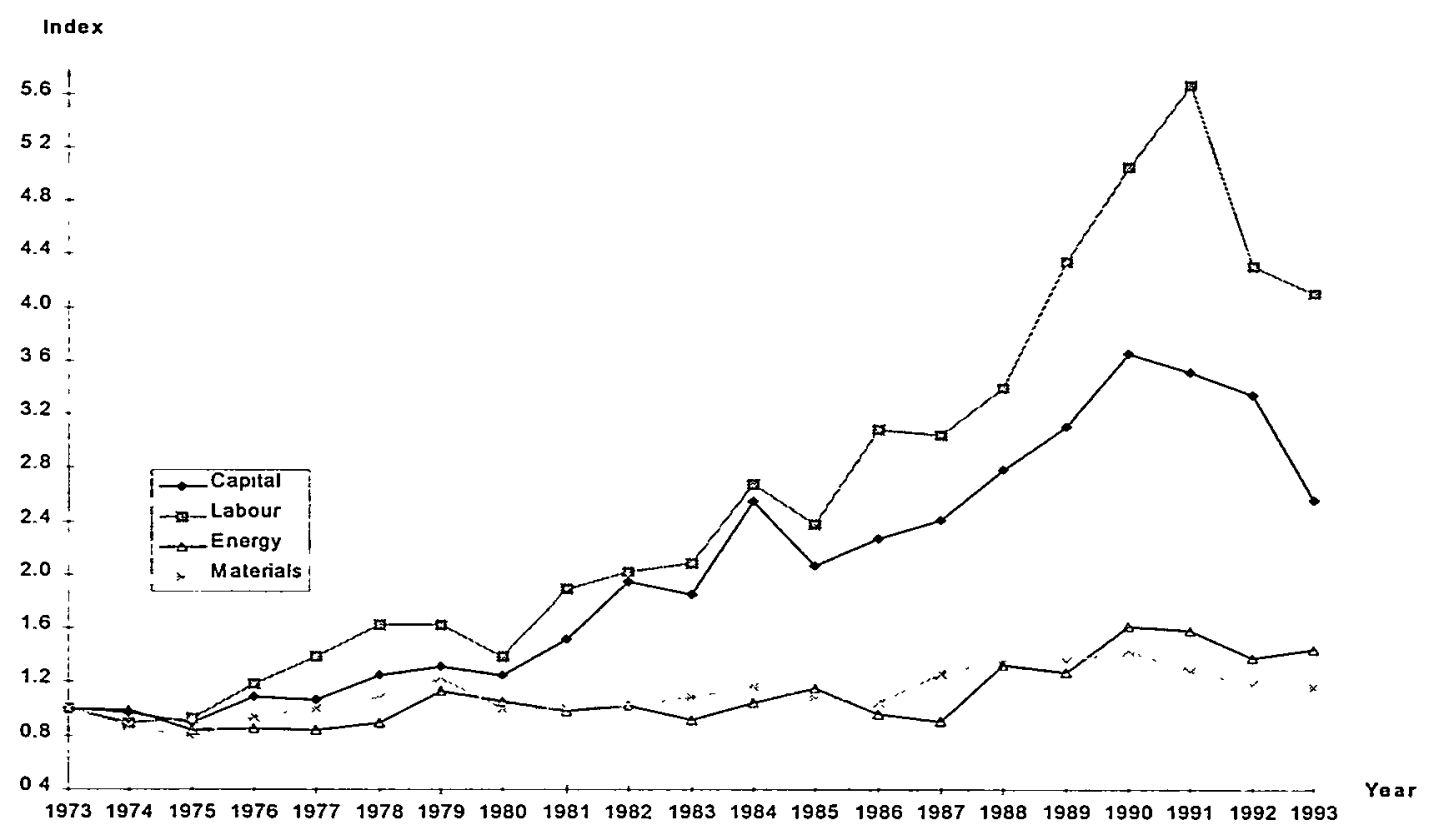

The examination of capital and labor in relation to gross value added rather than gross value of output confirms the results for capital and labor productivity. The results are similar in terms of direction and size of change indicating an overall positive development of partial productivity that was mainly supported by enormous increases in productivity in the 1980s. The increase in labor productivity is to some extent the result of the process of capital deepening, the increasing use of capital per head, indicated by a growth in the capital labor ratio at $1.76 \%$ p.a. Resources have shifted from labor to the use of capital over time. 


\subsubsection{Total Factor Productivity}

Total factor productivity relates the input factors capital and labor to gross value added. It measures the growth in gross value added (GVA) that can not be explained by the growth of a weighted combination of the two inputs capital and labor.

Figure 3.6 shows the development of total factor productivity as measured by the Kendrick, Solow and Translog Index over time. In addition, Table 3.2 gives total factor productivity growth for different time periods. The growth rates for the Kendrick and the Solow index are estimated as compound growth rates. The Translog index, however, is based on the assumption of exponential growth due to its logarithmic, non-linear nature. Trend rates calculated as semi-logarithmic trends are also given.

Table 3.2: Total Factor Productivity Growth (selected time periods, per cent p.a.)

\begin{tabular}{|l|ccc|}
\hline Growth & Translog & Solow & Kendrick \\
\hline $1973-93$ & 4.19 & 2.44 & 4.24 \\
$1973-79$ & -0.10 & -1.48 & -0.16 \\
$1979-91$ & 7.92 & 6.19 & 8.19 \\
$1991-93$ & -5.35 & -7.16 & -5.07 \\
\hline Time Trend & & & \\
$1973-93$ & 6.64 & 4.71 & 6.59 \\
\hline
\end{tabular}

Note: Translog: Exponential Growth; Solow, Kendrick: Compound Growth. Trend Rate calculated as semi-logarithmic time trend, significant on $5 \%$ level.

Figure 3.6: Index of Total Factor Productivity based on 1973-74 constant values

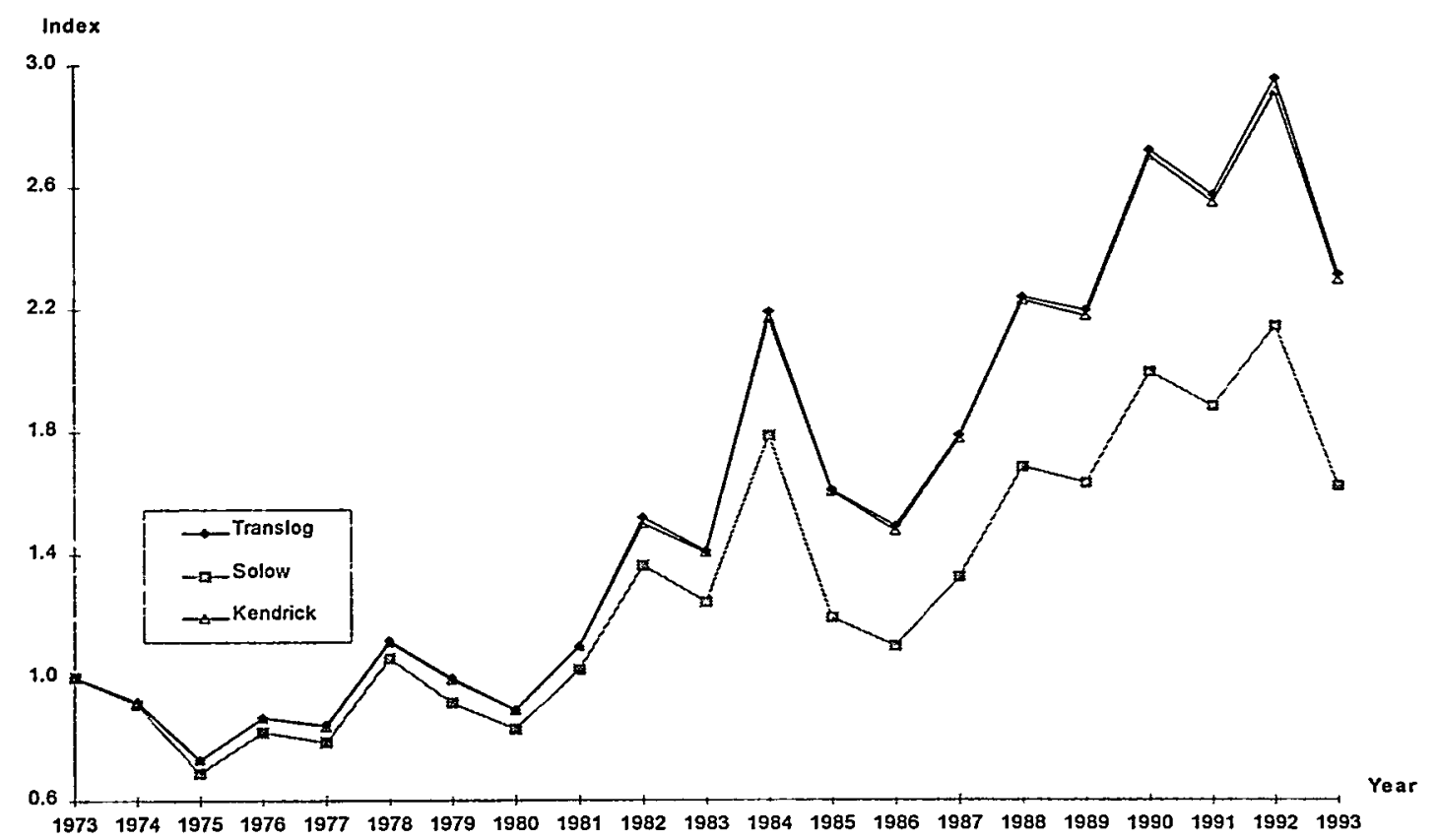


The three indices are related in their patterns, particularly the Translog and Kendrick index that are almost identical in value and growth. The Solow index is continuously lower both in absolute and relative terms. Similar to the evolution in partial productivity one can observe an overall positive development of total factor productivity between 1973 and 1993 indicated by an average growth of $6.64 \%$ p.a. (Translog), $4.71 \%$ p.a. (Solow) and $6.59 \%$ p.a. (Kendrick). The progress is mainly driven by the period of success in the 1980s. As with labor and capital productivity total factor productivity experiences a peak in 1984, however, followed by a downfall in 1985 and 1986.

The first period, 1973-79, shows an overall slightly negative growth due to decreases in total factor productivity in the first three years as well as around 1979. However, with the beginning of the 1980s this trend reverses and total factor productivity advances at fast rates (Translog: $7.92 \%$, Kendrick: $8.19 \%$ and Solow: $6.19 \%$ ). Following policy change towards decontrol of the fertilizer sector a turnaround can be observed in 1992. Between 1991 and 1993 all three indices reveal falling factor productivities at rates ranging from $5.07 \%$ p.a. (Kendrick) to $-7.16 \%$ p.a. (Solow).

\subsubsection{Total Productivity}

Total productivity measures the growth in gross value of output in excess of the growth of a weighted combination of the inputs capital, labor, energy and material. As with total factor productivity we consider three different indices for measuring total productivity.

Table 3.3 and Figure 3.7 present the growth of the three indices and their evolution over time. Total productivity shows a more stable pattern than total factor productivity. Over the total period of 1973 to 1993 , all three indices are increasing at very similar rates. The Translog index gives highest growth at an average $3.81 \%$ p.a., while the Kendrick index is lowest at an average $3.36 \%$ p.a.

Table 3.3: Total Productivity Growth

(selected time periods, per cent p.a.)

\begin{tabular}{|l|ccc|}
\hline Growth & Translog & Solow & Kendrick \\
\hline $1973-93$ & 2.31 & 2.16 & 2.05 \\
$1973-79$ & 3.87 & 4.10 & 3.95 \\
$1979-91$ & 3.32 & 3.04 & 2.59 \\
$1991-93$ & -8.44 & -8.30 & -6.42 \\
\hline Time Trend & & & \\
$1973-93$ & 3.81 & 3.68 & 3.36 \\
\hline
\end{tabular}

Note: Translog: Exponential Growth; Solow, Kendrick: Compound Growth.

Trend Rate calculated as semi-logarithmic trend, significant on $5 \%$ level.

Besides a decrease in total productivity in the first three years, the first subperiod reveals a strong increase in total productivity. Total productivity growth ranges from $3.87 \%$ p.a. (Translog) to $4.10 \%$ p.a. (Solow) for the period 1973-79. The second subperiod, the period of success (179-91), experiences a minimally smaller growth at an average $2.59 \%$ p.a. (Kendrick) to an average $3.32 \%$ p.a. (Translog). As with total factor productivity 
growth a peak in total productivity can be observed in 1984 followed by a decline in the two subsequent years.

Total productivity culminates in 1990 when the trend abruptly reverts to a very negative development. The period of 1991-93 shows a sharp decrease at $-6.42 \%$ p.a. for the Kendrick index, $-8.30 \%$ p.a. for the Solow index, and $-8.44 \%$ p.a. for the Translog index.

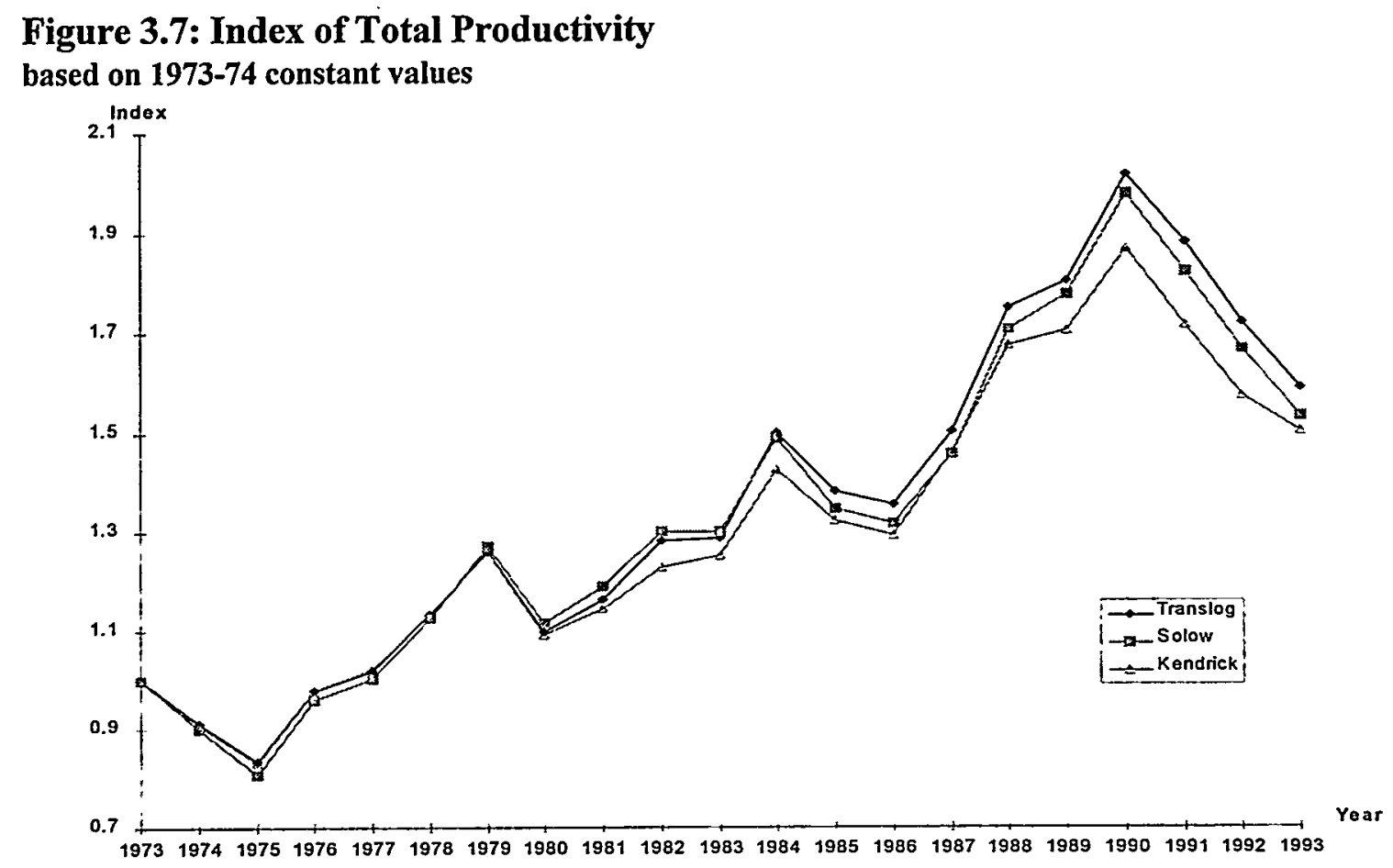

\section{Decomposition of Growth in Value of Output}

A very insightful way of looking at growth in output is to decompose growth into the contribution of factor input changes and total productivity growth. Generally, growth in production is two-folded consisting of increased use of inputs and some additional change (gain or loss) in productivity. As mentioned, growth in productivity thereby includes technological change, learning, education, organization and management improvements etc. The two-folded base of growth in output can naturally imply that growth in output is accompanied by increase in factor input and decrease in productivity, by.decrease in factor input and increase in productivity or by increase in both factor input and productivity. Table 3.4 presents the decomposition results for our study period and the subperiods identified above.

Table 3.4 shows overall output in the fertilizer sector measured as average exponential growth of gross output following a positive course at $10.1 \%$ p.a. growth over the period 1973-93. The decomposition analysis reveals that productivity gain contributed $2.31 \%$ 
p.a., about one fifth, to total output growth while the remaining growth was achieved by increases in use of factor inputs.

Table 3.4: Decomposition of Growth in Value of Output

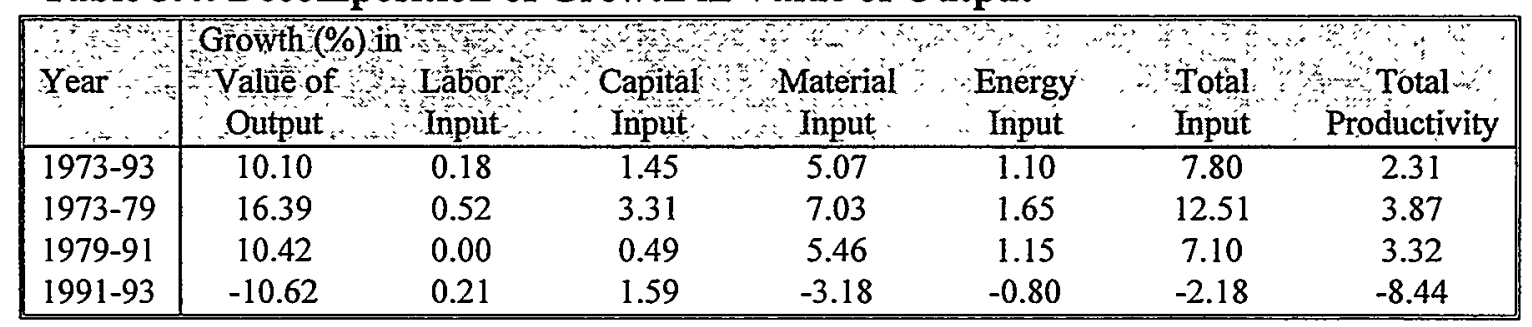

The first period shows a higher than average output growth (16.39\% p.a.) for the years 1973-79. Total productivity increase accounts for $3.87 \%$ p.a., slightly less than one fourth, of output growth. A bit more than $75 \%$ of output growth is due to rising input factors $(12.51 \%$ p.a.), particularly material inputs (7.03\% p.a.). Notably, productivity growth is higher than growth in either of the three other factors. The following period shows very similar behavior. Output grows at $10.42 \%$ p.a. between $1979-91$. Again, the growth can be mainly attributed to increases in total factor inputs ( $7.1 \%$ p.a.). The main contributor is growth in material inputs $(5.46 \%$ p.a.), followed by growth in energy input $(1.15 \%$ p.a.). Productivity growth accounts for around one third of output growth increasing at $3.32 \%$ p.a. during that period.

Following the introduction of liberalization measures, output declines considerably at $10.62 \%$ p.a. between 1991 and 1993. The fall-down is due to both losses in productivity as well as decreases in total inputs. Again, material input is a driving factor of output behavior. Between 1991-93, material input declines at $-3.18 \%$ p.a. However, productivity loss presents the single largest contributor to output loss decreasing at $-8.44 \%$ p.a. and thus accounting for more than $80 \%$ of output loss.

\subsection{Econometric Analysis}

\subsubsection{Previous Studies}

The accounting framework employed for the derivation of total and total factor productivities does not explain why factor demand changes over time. However, understanding substitution processes between input factors and the effects of factor price changes on input use is crucially important for determining the rate and direction of technological change and thus productivity growth. Few researchers so far have tried to tackle this issue in econometrically estimating production or dual cost functions and concluding patterns and relationships between input factors. 


\subsubsection{Own Estimates}

Our results for the econometric estimation of productivity change and patterns of input substitution are received from both the statistical analysis and from estimating a translog cost function approach with four input factors: capital, labor, energy and material. For a detailed presentation of the economic framework, the specifications and the resulting estimations see Roy et al. (1998). The following tables extract from her results and present the most important and most interesting findings to our analysis.

Our analysis focuses on productivity growth in energy intensive industries. Accordingly, energy prices and energy price changes over time play a dominant role. Therefore, Table 3.5 presents the elasticities of the cost shares ${ }^{2}$ for each input with respect to changes only in energy prices. The technical bias parameter is reported for all factor inputs and is crucially important for understanding direction and rate of technological change. It indicates which of the factors have been substantially made use of in the process of technological change.

Table 3.5: Estimated Parameters for the Translog Cost Function Approach

\begin{tabular}{|l|l|l|l|l|l|l|l|l|l|}
\hline Parameter & $\mathrm{b}_{\mathrm{me}}$ & $\mathrm{b}_{\mathrm{le}}$ & $\mathrm{b}_{\mathrm{ke}}$ & $\mathrm{b}_{\mathrm{ec}}$ & $\mathrm{b}_{\mathrm{mt}}$ & $\mathrm{b}_{\mathrm{lt}}$ & $\mathrm{b}_{\mathrm{kt}}$ & $\mathrm{b}_{\mathrm{et}}$ & $\mathrm{b}_{\mathrm{tt}}$ \\
\hline & 0.009 & -0.021 & -0.098 & 0.109 & 0.004 & -0.003 & -0.006 & 0.004 & -0.001 \\
$\mathrm{t}$-value & $(0.098)$ & $(-1.135)$ & $(-2.307)$ & $(1.577)$ & $(0.989)$ & $(3.052)$ & $(-2.973)$ & $(1.492)$ & $(-0.135)$ \\
\hline
\end{tabular}

$b_{i j}=$ elasticity of share of ith input with respect to the change in the price of jth input

$\mathrm{b}_{\mathrm{it}}=$ technical bias parameter

Regarding the cost share elasticities the table shows that the cost shares of labor and capital decrease with rising energy prices while the cost share of material increases with rising energy prices. However, only the value for the energy capital relationship is significant. The parameter $b_{t t}$ indicates a slight but insignificant acceleration of technical change over time. As shown in the previous section productivity in the fertilizer sector has been increasing over time. Thus, a significant positive technical change parameter, as expressed by a significant negative value for $b_{t t}$, would indicate that this advance has been increasing over time. Changes in productivity usually affect the input factors differently. The technical change bias parameters here indicate a significant capital and labor savings bias and an insignificant energy and material using bias (Table 3.6).

Table 3.6: Technical Change Bias

\begin{tabular}{|c|c|c|c|c|c|}
\hline$\because \cdots$ & Capital & Labor & ; & Energy & Material \\
\hline Technical Change & saving & saving & & using & using \\
\hline
\end{tabular}

For the analysis of patterns of substitution and effects of price changes on the immediate use of input factors the cross price elasticities are of particular interest. The price elasticity shows the extent to which the input of one factor changes in response to a price change of one other input factor. A positive cross price elasticity indicates a substitutional

\footnotetext{
${ }^{2}$ Cost shares are defined as factor input costs over total input costs (sum of capital, labor, energy and material costs).
} 
relationship between the two input factors considered. It gives an increase in factor demand of factor $i$ due to a decrease in factor price $j$ which itself leads to a reduction in demand for factor $j$.

Table 3.7: Price Elasticities

\begin{tabular}{|c|c|c|c|c|c|c|c|}
\hline & $\begin{array}{l}\text { Price } \\
\text { Elasticity }\end{array}$ & 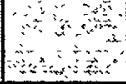 & $\begin{array}{l}\text { Price } \\
\text { Elasticity }\end{array}$ & & $\begin{array}{l}\text { Price } \\
\text { Elasticity }\end{array}$ & 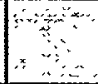 & $\begin{array}{l}\text { Price } \\
\text { Elasticity }\end{array}$ \\
\hline $\mathrm{KK}$ & -0.376 & LK & 0.443 & EK & -0.452 & MK & 0.190 \\
\hline $\mathrm{KL}$ & 0.136 & LL & -0.411 & $\mathrm{EL}$ & -0.077 & $\mathrm{ML}$ & 0.016 \\
\hline $\mathrm{KE}$ & -0.362 & $\mathrm{LE}$ & -0.201 & $\mathrm{EE}$ & -0.132 & $\mathrm{ME}$ & 0.167 \\
\hline $\mathrm{KM}$ & 0.603 & LM & 0.169 & EM & 0.661 & MM & -0.374 \\
\hline
\end{tabular}

The price elasticities are shown in Table 3.7. All own price elasticities are negative as required by theory. The labor price elasticity is highest with -0.411 , followed by capital price elasticity, -0.376 , material price elasticity, -0.374 and an energy price elasticity of -0.132 .

Table 3.8: Elasticities of Substitution - Qualitative Overview

\begin{tabular}{|c|c|c|c|}
\hline$-\cdots \cdots \cdots$ & Energy & Labor & Capital \\
\hline $\begin{array}{l}\text { Material } \\
\text { Energy } \\
\text { Labor }\end{array}$ & substitutes & $\begin{array}{l}\text { substitutes } \\
\text { complements }\end{array}$ & $\begin{array}{l}\text { substitutes } \\
\text { complements } \\
\text { substitutes }\end{array}$ \\
\hline
\end{tabular}

Cross price elasticities indicate substitutional relationship for all input factors except energy and labor and energy and capital (Table 3.8). Thus, a rise in, for example, energy prices will lead to increased use of material inputs to substitute for the more expensive energy input. However, capital and to a smaller extent labor will be less intensively used as they present complementary inputs to energy. Among the input factors, the relationship between energy and material is most elastic. A $10 \%$ increase in material price would lead to a $6.6 \%$ increase in energy input while at the same time material use would decrease by $3.7 \%$. However, it needs to be noted that with all resulting elasticities being relatively modest, overall input factors are only moderately elastic.

\subsection{Discussion}

The results described in the previous section need to be set in context of actual changes in both structural composition and policies within the fertilizer sector over the last 20 years to better understand the factors driving technological change and productivity growth.

As shown above, productivity in the fertilizer sector has been increasing over time. Productivity gains were strongest in the second half of the 1980s. The split-up of the time range into three subperiods $(1973-79,1979-91,1991-93)$ is in accordance with structural and policy changes in the sector. Two major policy changes took place in 1977-79 and 1991/92 when first the retention price system for fertilizer was implemented and later liberalization measures including the withdrawal of all price and distribution controls for phosphatic and potassic fertilizers were introduced. 
Productivity gain was high ( $3.87 \%$ p.a.) in the first subperiod under consideration contributing more than one third to growth in output. However, increased use of input factors, particularly material and capital (together $10.34 \%$ p.a.), presented the main drivers of output growth $(16.39 \%$ p.a.) during that time. The fertilizer industry is one of the only energy intensive industries that did not show any significant negative long term reaction to the two oil price shocks in 1974 and 1979, although input costs increased exceptionally at these points of time. Short term decreases in both output and productivity can be observed for the years 1974, 1975 and 1980 only. Policies pertaining to the industry may have been well effective in absorbing most of the negative consequences. These policies were directed at ensuring fertilizer availability to farmers at reasonable prices through subsidization.

During the following subperiod 1979-91, total control and high subsidization through the retention price system seem to have helped preserve the upward trend of the fertilizer sector. Output grew at an average $10.42 \%$ p.a. in this period, about one third due to improvements in productivity and the remaining due to increased use of factor inputs. Among the factor inputs increased use of material inputs contributed most to output growth, while at the other end labor input did nearly stagnate. Most of the growth both in output as well as productivity was achieved during the second half of the 1980 s.

In the 1980s, consumption of fertilizer also stepped significantly forward, doubling from 5.52 Mt in 1980-81 to $12.55 \mathrm{Mt}$ in 1990-91. Due to increased domestic production, imports at the same time remained level at $2.76 \mathrm{Mt}$ and were mostly related to the import of potassic fertilizer that could not be produced domestically. Although the policy system of retention prices was originally thought to be self-financing a closer look at subsidy figures points out that subsidies possibly were the main single factor driving the immense progress of fertilizer supply and demand. Subsidies increased more than eightfold between 1980-81 and 1990-91 from 5,050 million Rs. to 43,890 million Rs.

The policy of retention prices included incentives to improve the economics of plants. For example, in linking individual retention prices to a fixed norm on capacity utilization, individual firms profits became crucially dependent on meeting the capacity utilization rate. Moreover, assured demand by government policy encouraged firms both to fully utilize existing capacity and to set up new capacity. In this view, capacity utilization in India's fertilizer plants improved from less than $60 \%$ in $1979-80$ to almost $90 \%$ in 1991 92. While the development of nitrogenous plants shows a very steady path advancing continuously over time, phosphatic fertilizer plants reveal an up and down of capacity utilization reaching a low in 1979-80 (66\%) and an up in 1991-92 (92\%).

Further economic advances can be attributed to increased relative sizes of plants allowing firms to appropriate economies of scale. Between 1980 and 1990, installed capacity doubled from $5.18 \mathrm{Mt}$ to $10.19 \mathrm{Mt}$ while at the same time the number of plants increased by about $40 \%$ only. Besides government interventions, these improvements are partly due 
to the discovery of major indigenous gas reserves in the $1980 \mathrm{~s}$ that led to the establishment of additional high capacity gas based ammonia plants.

The last time period, 1991-93, shows a complete turnaround from the progress experienced in the previous period. Liberalization measures such as the withdrawal of price and distribution control for potassic, phosphatic and low analysis nitrogenous fertilizers together with the introduction of dual pricing including a $30 \%$ price increases of fertilizer sold to large scale farmers, and the anticipation of further decreases of subsidies showed immediate effects on production patterns. Output decreased on average by about the same rate it had increased in the period 1979-91 $(-10.62 \%$ p.a.). Due to the nature of the policy changes and subsidy schemes towards relatively stronger support of nitrogenous fertilizers the reduction in production, import and use of phosphatic and potassic fertilizers was significantly higher.

Total productivity declined at a high rate of $-8.44 \%$ p.a. To a large extent, this decline is due to reduced capacity utilization caused by downfall in production, rather than being a consequence of lack of technical progress. High levels of uncertainty particularly regarding future policies and subsidy schemes, regarding the effects on demand and prices, and the availability of raw materials (aggravated by the Gulf War) placed substantial burden on the industry. However, from 1994 on with resumed subsidy payments a recovery can be observed.

Overall, the introduction of the retention price system seemed highly effective in stimulating the fertilizer industry as supported by our analysis. However, sustaining this growth required ever increasing amounts of government subsidies. Economic liberalization has led to the reduction of government support in the fertilizer industry since 1991 with immediate effects that seem rather depressing. The long term effects, however, are far from being clear so far.

The study shows that technical change has been biased towards relatively less use of capital and labor inputs. A labor savings bias seems in contrast to India's relatively cheap and abundant labor force. However, heavy industries like the fertilizer industry are usually not labor intensive since manual labor is substituted by machinery and other technology. In addition, technology transfers from more industrialized countries with high labor costs very often implicitly import a labor saving bias to India. In comparison to other energy intensive industries in India, fertilizer production is relatively little energy using. Moreover, the study shows that energy productivity has been improving over time. Nevertheless, the development of energy prices is of particular interest. Our study shows an energy using bias although at insignificant levels. An increase in energy prices through policy or world market changes would impose relatively higher costs if the nature of the industry's technical progress would be significantly biased towards the use of energy. Technological change and productivity growth would be reduced. The analysis further reveals that labor and capital inputs are complementary to energy use. An increase in energy prices would therefore reduce demand for labor and capital. However, inter-input substitution possibilities are limited. 


\section{Future Development of the Fertilizer Sector}

\subsection{Ongoing Changes in the Fertilizer Industry}

The fertilizer industry today as in the past faces major challenges. Continued supply and use of fertilizer is important to ensure the country's food security goal. Foodgrain production was declining in the most recent past (e.g. between 1994-96) potentially jeopardizing this goal (Government of India, Department of Agriculture and Cooperation, 1999; Trivedi, 1998). The industry's challenges relate to the uncertainty in the supply and pricing of feedstock, especially of natural gas and naphtha, low efficiency and small size of older plants, high investment costs, infrastructural bottlenecks and an uncertain policy environment.

The current composition of ammonia plants in terms of age, capacity and feedstock is presented in Table 4.1. The table shows that plants installed before 1980 are small in size using less efficient feedstock. Plants installed in the 1980s are relatively large and employ more efficient feedstock whereas plants built during the 1990s are nearly world-scale in terms of feedstock use.

Table 4.1: Age, Number, Installed Capacity and Feedstock of Ammonia Plants in India

\begin{tabular}{|l|cccc|}
\hline Year of Installation & 1951 to 1970 & 1971 to 1980 & 1981 to 1990 & 1991 onwards \\
\hline Number of Plants & 10 & 15 & 11 & 4 \\
Share in Total & $25 \%$ & $38 \%$ & $28 \%$ & $10 \%$ \\
\hline Aggr. Installed Capacity (tpd) & 4622 & 10815 & 14930 & 3872 \\
Share in Total & $14 \%$ & $32 \%$ & $44 \%$ & $11 \%$ \\
\hline Average Plant Size (tpd/plant) & 462 & 721 & 1357 & 968 \\
\hline Feedstock Demand (tpd) & 1000 & 1510 & 10950 & 3872 \\
NG/AG & 2722 & 5420 & 1730 & - \\
Naphtha & 900 & 2885 & 1350 & - \\
Fuel Oil/LSHS & - & 900 & 900 & - \\
Coal & \multicolumn{5}{|r}{} \\
\hline Source: Trivedi (1998).
\end{tabular}

Natural gas is the preferred feedstock to the fertilizer industry. Gas based plants are more efficient than plants based on other feedstock and thus produce at lowest cost. Although under government control feedstocks were individually assigned to plants, gas based fertilizer plants have been supplied with gas barely sufficient to meet the feedstock requirements. In addition, the calorific value of gas has been decreasing. Demand of gas from the fertilizer industry is in competition with demand from the high priority power sector. In the process of industrial liberalization, the government intends to eventually decontrol the prices of various feedstocks. Price and quantity concessions to the fertilizer industry might then be withdrawn leading to price increases for supply to the fertilizer industry much higher than to other industries in order to reduce the existing price 
differential. With respect to the food security goal this would lead to a need for tremendously increased subsidies.

In view of the uncertainty regarding the availability of feedstock and due to recent policy changes towards liberalization and reduction of subsidies, no investment into setting up new capacity has been taken since the early 1990s. Additions in capacity in the 1990s resulted from projects planned in the $1980 \mathrm{~s}$ but commissioned in the 1990s. However, revamping and modernization options are being explored. In order to reduce production costs capacity utilization and energy consumption need to be improved. Energy saving technological developments are being commercialized and technologically advanced processes are being adopted. Furthermore, joint venture projects are being envisioned, in particular for phosphatic fertilizer where production is completely based on imported raw materials.

The government has constituted a new fertilizer pricing policy review committee (HPC) that was asked to review the existing system of subsidization of urea and suggest an alternative broad based scientific and transparent methodology and recommend measures for greater cohesiveness in policies. Policies have led to a currently heavily imbalanced use of fertilizers through decontrolled high price potassium and phosphatic fertilizers and artificially low urea prices. Furthermore, urea imports reached a peak of 3.77 million tonnes in 1995-96 contributing further to the imbalance in fertilizer use. (National Information Center, 1999)

\subsection{Potentials for Energy Efficiency Improvements}

\subsubsection{India versus Best Practice}

Table 4.2 presents energy savings potentials by comparing specific energy consumption in Indian ammonia plants with specific energy consumption that could be achieved if particular revamp and modernization efforts would be undertaken. A typical energy efficiency revamp of a plant would reduce specific energy consumption for plants installed before 1980 by 1.2 to $3.2 \mathrm{Gcal} / \mathrm{t}$ and for plants installed between 1981-1990 by about 0.8 to $1 \mathrm{Gcal} / \mathrm{t}$ depending on the feedstock used. Plants installed after 1991 are already highly efficient and meet world best standards. Currently, there are only two coal based plants accounting for a small share of installed capacity. They are high energy consumers and do not promise significant energy saving potentials. With a production capacity of 11.3 Mt per year, overall energy savings amount to 14.12 Pcal per year (Trivedi, 1998).

The age of the technology, the scale of the plant and management practices have a large impact on energy efficiency of the overall process. Energy savings potential are highest for naphtha and fuel oil/LSHS based plants especially for plants built before 1980. A closer look at all pre-1980 plants reveals that with current installed capacity of $5.09 \mathrm{Mt}$, energy savings in the pre-1980 ammonia plants alone would account for up to $11 \mathrm{Pcal}$ per 
year. This means, with a share of less than $50 \%$ in total installed capacity energy savings in these plants alone would be more than $75 \%$ of total possible energy savings.

Table 4.2: Energy Savings Potential -All Ammonia Plants: Broad Estimates

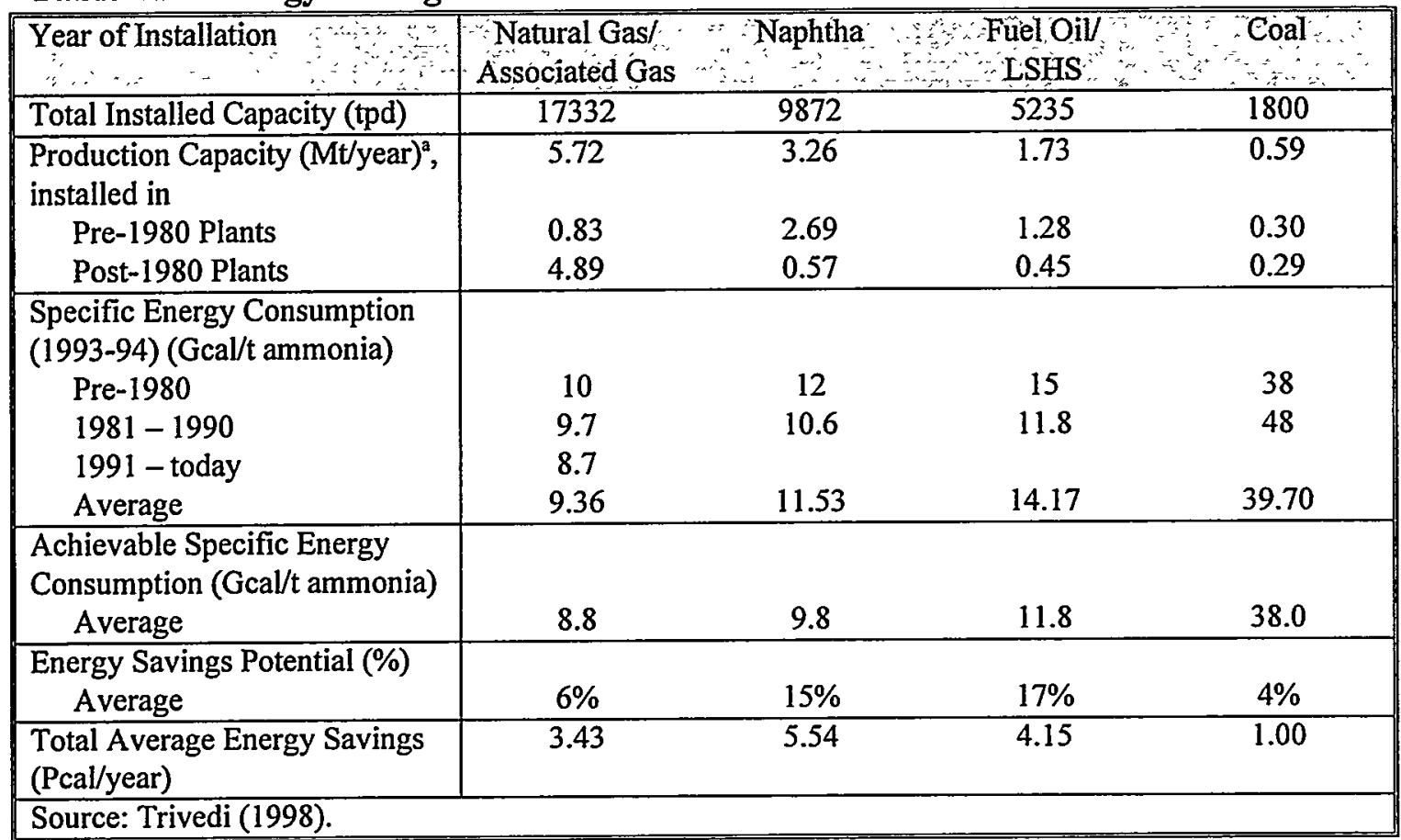

${ }^{3}$ The maximum operation period of a plant is 330 days a year. ${ }^{b}$ average for all ammonia plants.

The scale of the plant matters significantly for energy consumption. Therefore revamp options (as described in more detail below) typically include a capacity increase for the plant. This will help meeting future demand which is expected to grow at $3 \%$ annually between 1997 and 2001.

\subsubsection{Categories for Energy Efficiency Improvement}

The following factors have already been identified as affecting energy consumption in ammonia-urea plants: capacity utilization, type of feedstock, technology employed, and vintage of the plant. Since ammonia-urea plants built more recently already reach worldbest efficiency levels focus here is placed on pre-1980s and 1980s plants. For an older ammonia plant a typical revamp would include the following: a) capacity increase, b) energy-saving, c) reduction in raw material and utility consumption, d) reduction in environmental impact, e) improved safety and reliability, and f) improved control systems. All of this would directly or indirectly benefit energy consumption.

Specifically, improvements to the energy efficiency of various process components of ammonia (and to a lower extent of urea) include improvements in the reforming, $\mathrm{CO}_{2}$ removal, synthesis, and purge gas recovery (all of these can further broken down into process optimization, maximization of heat recovery, and the fine-tuning of process parameters), and energy savings from development of new and better catalysts and 
improved metallurgy leading to superior and more efficient process equipment. For a more detailed description of these measures and their actual energy savings potentials see Trivedi (1998).

\subsubsection{Barriers to Energy Efficiency Improvement}

Although integrating energy savings measures and technologies in all plants would lead to net savings both in terms of energy and overall costs, only few measures have been or are currently being implemented in the Indian fertilizer sector. Barriers to energy efficiency improvement are of both general and firm/process specific nature. A 5-6 year payback period is one of the barriers to energy-saving investment.

At the macro level, government policy towards liberalization and the pressure to reduce subsidies create uncertainty and pose challenges to adoption of more energy efficiency. As energy prices were regulated in the past and feedstocks assigned to the plants, energy costs were almost taken as fixed by the plant and little incentive was prevalent to reduce energy consumption. The energy price elasticity as shown in section 3.2.2 was low at 0.13 . However, one should keep in mind that in a regulated energy market for fertilizer production, price elasticities do not fully display a firm's actual behavior to price signals as they would do in a deregulated, truly competitive market. Therefore, energy price signals may be more effective in stimulating energy conservation than concluded from the economic analysis. Further, firm-level barriers to the adoption of energy efficiency improvement include significant capital requirements, lack of appreciation for reducing energy use and familiarity with the technical and commercial aspects of energy efficiency and environmental management.

Although in view of the uncertainties regarding the policy environment and feedstock supply, revamping programs present the preferred option over setting up new plants, there are still many barriers related to these. Limitations imposed by existing plant layout and technology and utility systems in use may rule out the possibility of introducing new developments. Moreover, pre-revamp activities such as identifying bottlenecks, evaluating available technological options and their commercial impact, assessing plant layout and constraints of the existing set-up are very complex and require a well coordinated effort amongst various disciplines. (Trivedi, 1998)

\section{Summary and Conclusions}

In this paper, we investigated India's fertilizer sector from various perspectives. We developed economic as well as engineering indicators for productivity growth, technical change and energy consumption that allowed us to investigate savings potentials in specific energy use. We discussed our findings within a broader context of structural and policy changes in the sector. The economic analysis showed that productivity was increasing over time. The increase took place during the era of total control when the retention price system and distribution control was in effect. The retention price system was coupled with relatively high norms on capacity utilization which supported 
productivity increase. With liberalization of the fertilizer sector and reduction of subsidies productivity declined substantially since the early 1990 s, despite an increase in capacity utilization.

We further pointed out options for reducing energy consumption in the fertilizer industry. In comparing current energy consumption to best achievable energy consumption energy savings of up to $17 \%$ could be achieved. However, the implementation of initiatives towards energy efficiency is being hampered by barriers both of general and process specific nature occurring at the macro and micro level of the economy.

Energy policies in general and price-based policies in particular can help overcome these barriers in giving proper incentives and correcting distorted prices. Appropriate provisions should be made in the retention pricing scheme to further encourage investment in energy conservation projects. Originally, normative consumption of various inputs was taken into account under the retention price system which encouraged the implementation of energy efficiency measures. These and other fiscal incentives need to be reinstated under the current scheme.

Through the removal of subsidies energy prices would come to reflect their true costs. In a deregulated market, firms would adjust their behavior in order to minimize costs of production. Therefore, in the short term, energy price increases would push less productive and inefficient mostly smaller units out of the market or force these units to take immediate initiatives to improve productivity and efficiency. On a long term basis, substantial further investments in energy efficiency technologies for existing and new plants have to be made. Therefore, sectoral policies should be devoted to the promotion of such investments. A stable foreseeable policy environment would substantially help firms to reduce the risk of taking large investments. Our economic results pointed out that technological change has been biased ${ }^{3}$ towards the use of energy inputs. This implies that price-based policies albeit effective in reducing energy use could have a negative long run effect on productivity, and thus welfare. An optimal policy strategy would therefore consist of a mix of regulatory and price based incentives within a set political and economic framework.

\footnotetext{
${ }^{3}$ significant at $15 \%$ level.
} 


\section{References}

Ahluwalia, Isher Judge, 1991: Productivity and Growth in Indian Manufacturing, Delhi, Oxford New York: Oxford University Press.

Ahluwalia, Isher Judge, 1985: Industrial Growth in India - Stagnation Since the MidSixties, Delhi, Oxford, New York: Oxford University Press.

Basu, P. and Madhukar H. Majmudar, 1994: "Policy Support for the Phosphatic Fertiliser Industry in India", in Challenges of Liberalisation in the Fertiliser and Agriculture Sectors, The Fertilizer Association of India, FAI Seminar December 1994, New Delhi, India.

Center for Monitoring the Indian Economy (CMIE), 1996: India's Industrial Sector, Economic Intelligence Service, India, January, 1996.

Datt, Ruddar and K.P.M. Sundharam, 1998: Indian Economy, New Delhi, Chand \& Company Ltd.

Government of India, 1999: Fertilizer Situation in INDIA, Department of Agriculture and Co-operation, http://www.nic.in/agri, National Informatics Centre (NIC).

Government of India (various years): Annual Survey of Industries: Summary Results for Factory Sector, 1973-93, Central Statistical Organisation, Department of Statistics, Ministry of Planning and Programme Implementation, New Delhi, India.

Kalra, G.D., 1989: Effectiveness of Incentives for Energy Saving Devices, New Delhi, India: National Council of Applied Economic Research.

Mittal, D.K., 1994: Fertiliser Industry, New Delhi, India, Anmol Publications Ltd.

Mongia, Puran B. and Jayant Sathaye, 1998: Productivity Trends in India's Energy Intensive Industries - A Growth Accounting Analysis, Lawrence Berkeley National Laboratory, 41838, Berkeley, California.

Mongia, Puran B. and Jayant Sathaye, 1998a: Productivity Growth and Technical Change in India's Energy Intensive Industries - A Survey, Lawrence Berkeley National Laboratory, 41840, Berkeley, California.

National Information Center, 1999: Fertilizer Situation in INDIA, Department of Agriculture \& Cooperation, Government of India, http://www.nic.in/agri/fertsit/htm.

Phylipsen, G.J.M., K. Blok, and E. Worrell, 1998: Handbook on International Comparisons of Energy Efficiency in the Manufacturing Industry, Dept. of Science, Technology and Society, Utrecht University, The Netherlands. 
Prasad, Rajendra and J.F. Power, 1994: "Balanced Fertilisation and Sustainable Agriculture in the Wake of Recent Policy Changes", in Challenges of Liberalisation in the Fertiliser and Agriculture Sectors, The Fertilizer Association of India, FAI Seminar, December 1994, New Delhi, India.

Roy, Joyashree, J. Sathaye, A. Sanstad, P. Mongia, and K. Schumacher, 1999: "Productivity Trends in India's Energy Intensive Industries", The Energy Journal, Vol. 20, No. 3, July.

Singh, Duleep and A.P. Srivastava, 1994: "Approach and Outlook of Likely Policy Environment of Nitrogenous Fertiliser Industry in India", in Challenges of Liberalisation in the Fertiliser and Agriculture Sectors, The Fertilizer Association of India, FAI Seminar, December 1994, New Delhi, India.

Subbiah, K.S., 1994: "Need for Effective Demand/Supply Management under Decontrolled/Decanalised Scenario", in Challenges of Liberalisation in the Fertiliser and Agriculture Sectors, The Fertilizer Association of India, FAI Seminar, December 1994, New Delhi, India.

Tandon, H.L.S. and Pratap Narayan, 1990: Fertilizers in Indian Agriculture: Past, Present and Future (1950-2000), Fertiliser Development and Consultation Organisation, New Delhi, India.

TERI, 1994: Teri Energy Data Directory and Yearbook 1994/95, Tata Energy Research Institute, New Delhi, India: Pauls Press.

TERI, 1996: Teri Energy Data Directory and Yearbook 1996/97, Tata Energy Research Institute, New Delhi, India: Pauls Press.

Trivedi, A.N., J. Sathaye, A. Gadgil, M. Mukhopadhyay, 1998: Energy Efficiency and Environmental Management Options in the Indian Fertilizer Industry, ADB Technical Assistance Project (TA:2403-IND), Forest Knolls, Calif.: ERI.

World Energy Council, 1995: "Energy Efficiency Improvement Utilising. High Technology: An Assessment of Energy Use in Industry and Buildings", prepared by: Marc D. Levine, Lynn Price, Nathan Martin and Ernst Worrell, London: World Energy Council.

Worrell, E., R.J.J. van Heijningen, J.F. de Castro, J.H.O. Hazewinkel, J.G. de Beer, A.P.C. Faaij, and K. Vringer, 1994: "New Gross Energy-Requirement Figures for Materials Production", Energy, Vol. 19 No. 6. 


\section{Appendix}

\section{Appendix A}

\section{Fertilizer Historical Estimates}

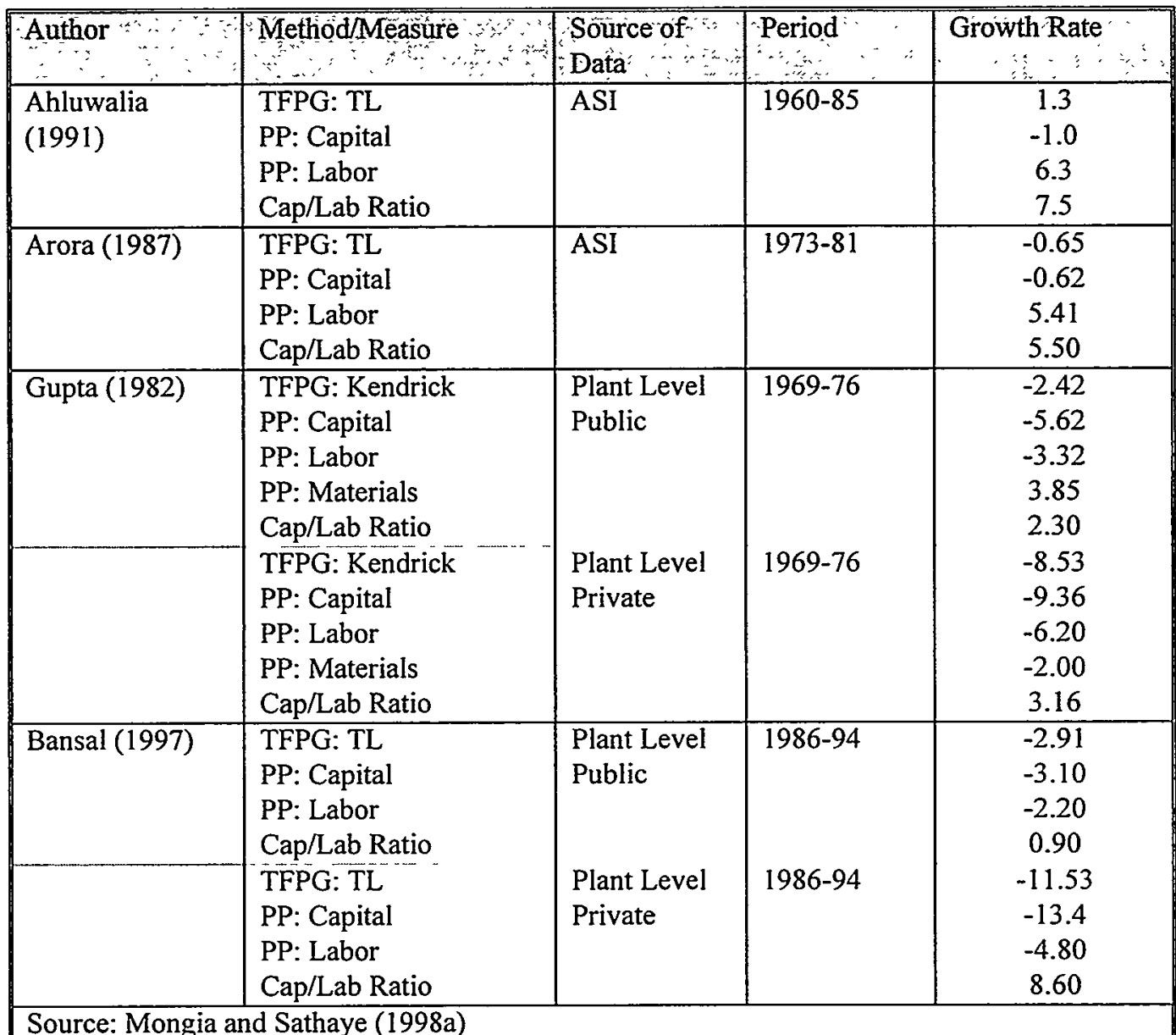

Note: Growth rates are per cent per annum, either compound annual growth rates, semi-log trend rates or simple average growth rates. 